\title{
Bank Capital (Requirements) and Credit Supply: Evidence from Pillar 2 Decisions*
}

June 26, 2019

\begin{abstract}
We analyze how time-varying bank-specific capital requirements affect bank lending to the non-financial corporate sector as well as banks' balance sheet adjustments. To do so, we relate Pillar 2 capital requirements to a comprehensive corporate credit register coupled with bank and firm balance sheet data. Our analysis consists of three components. First, we investigate how capital requirements affect the supply of bank credit to the corporate sector, both on the intensive and extensive margin, as well as for different types of credit. Subsequently, we document how bank and firm characteristics as well as the monetary policy stance impact the relationship between bank capital requirements and the supply of credit. Finally, we examine how time-varying bankspecific capital requirements affect banks' balance sheet composition.
\end{abstract}

Key words: Capital requirements, credit supply, credit register, bank regulation

JEL classification: G01, G21, G28, L5

${ }^{*}$ The authors would like to thank two anonymous referees, Margherita Bottero (discussant), Ferre De Graeve, Hans Degryse, Maite De Sola Perea, Mathias Efing (discussant), Stijn Ferrari, Giorgio Gobbi (discussant), Bjorn Imbierowicz, David Martinez Miera (discussant), Janet Mitchell, Klaas Mulier, Gert Peersman, Alexandre Reginster, Glenn Schepens, Ibolya Schindele (discussant), Bent Vale (discussant), Rudi Vander Vennet, Matjaž Volk (discussant), Raf Wouters. The paper has also benefited from discussions at various conferences: University of Groningen, Banque de France, 2016 Finest Winter Workshop, MPC Taskforce on Banking analysis for monetary policy (Vienna, 2017), Swiss Winter conference on Financial Intermediation 2017 (Lenzerheide), DNB-EBC-CEPR conference on "Avoiding and Resolving Banking Crises" (2017), 1st Bristol Workshop on Banking and Financial Intermediation (2017), IBEFA-ASSA 2018 (Philadelphia). This paper was initially prepared for the 2016 colloquium of the National Bank of Belgium entitled "The transmission mechanism of new and traditional instruments of monetary and macroprudential instruments". The authors gratefully acknowledge the financial support from the National Bank of Belgium. The views expressed are solely those of the authors and do not necessarily represent the views of the National Bank of Belgium. Ongena acknowledges financial support from ERC ADG 2016 - GA 740272 lending. 


\section{Introduction}

Following the Great Financial Crisis, there has been a robust consensus among policymakers that financial regulation needs a macro-prudential dimension on top of an improved micro-prudential and resolution framework. A prime tool, alongside borrower-based measures, of such micro- and macro-prudential supervision and policy is the use of time-varying bank capital requirements. ${ }^{1}$ Higher own funds requirements not only foster bank stability but can also soften credit-led booms, either because banks internalize more of the potential social costs of credit defaults (through a reduction in moral hazard by having more "skin in the game") or charge a higher loan rate due to the higher cost of bank capital (Morrison and White (2005), Adrian and Shin (2010), Shleifer and Vishny (2010), Adrian and Boyarchenko (2012), Jeanne and Korinek (2013), Malherbe (2015)). Indeed, the tax benefits of debt finance and asymmetric information about banks' conditions and prospects imply that raising external equity finance may be more costly for banks than debt finance (Tirole (2006), Freixas and Rochet (2008), Hanson et al. (2011), Aiyar et al. (2014b), Gornall and Strebulaev (2018)).

Despite the many research efforts now underway by academics to help develop macro-prudential policies (e.g., Galati and Moessner (2013)), no empirical study so far has comprehensively estimated the joint impact of both time-varying, individual bank required and actual capital ratios on the supply of bank credit to firms, and heterogeneity across bank and firm characteristics or due to monetary conditions.

This paper aims to fill this void by analyzing a series of policy experiments with changes in individual bank capital requirements in Belgium. ${ }^{2}$ From the adoption of the Twin Peaks supervisory model in April 2011 until the start of the Single Supervisory Mechanism in November 2014, the micro-prudential supervision of banks active in Belgium was the responsibility of the National Bank of Belgium (NBB). One of its micro-prudential instruments to maintain or achieve financial

\footnotetext{
${ }^{1}$ Under the new international regulatory framework for banks - Basel III - regulators agreed to vary minimum capital requirements over the cycle, by instituting procyclical bank capital requirements. In this terminology, procyclical bank capital requirements generate countercyclical capital buffers that deal with the procyclicality of the financial system. Boosting equity in booms provides additional (countercyclical) buffers in downturns that help mitigate credit crunches.

${ }^{2}$ We customarily designate these changes in individual bank required capital ratios as "experiments", though micro-policy shocks like these are never (intentionally) randomized and banks dealing with different types of borrowers may be differentially affected. Therefore, both these confidential shocks and comprehensive micro data are necessary for identification.
} 
stability was the bank-specific capital requirement (Pillar 2 capital requirement under Basel II) communicated directly to the bank but otherwise kept confidential. The resultant series of individual bank capital requirements coupled with comprehensive bank-, firm-, and loan-level data provide an almost ideal setting for identification and comprehensive assessment of their impact.

In the first part of our analysis, using loan-level data, we find that the joint increase in the required and actual capital in particular leads to a contraction in the supply of credit to firms, on all margins of credit granting. The fact that higher capital requirements lead to lower credit supply seems to indicate that equity capital costs for banks are not necessarily negligible, challenging the views of Admati et al. (2013) and Admati and Hellwig (2013). Therefore, in the second part of our analysis, mobilizing all aforementioned datasets, we inspect whether or not the impact of required capital on credit supply varies with bank and firm characteristics. In particular, we shed light on which frictions or costs affect raising actual equity as well as which firms will be affected more by banks' goal to reduce risk-weighted assets in response to tougher capital requirements. We find that smaller, riskier, or less profitable banks especially tend to reduce credit the most and that the resultant credit contraction mostly affects large, risky and low-borrowing-cost firms. Banks' business model characteristics seem to play less of a role in the transmission of capital requirements in credit supply. In the final part of our analysis, using bank-level data, we find that increases in required bank capital ratios shrink banks' balance sheets, mortgage and term lending, securities holdings, and deposit collecting while spurring interbank lending and borrowing.

This study differs from existing bank capital literature in several ways. First, we differ from many earlier studies that focus on the impact of shocks to actual bank capital and not on changes in regulatory requirements. Bernanke and Lown (1991), Berger and Udell (1994), Berrospide and Edge (2010), among many others, rely on a panel, vector autoregression or matching analysis of bank-level data, while Hubbard et al. (2002), Ashcraft (2006), Mora and Logan (2012) and Berger and Bouwman (2013), among others, focus solely on bank-level credit growth or cost. Likewise, Peek and Rosengren (2000) and Puri et al. (2011), among others, exploit the negative shocks to the profitability of multinational banks that occur abroad and that may affect actual bank capital. Moreover, most of these studies use bank-level data.

Second, in terms of our individual bank policy experiments, we are closest to Aiyar et al. (2014a), Aiyar et al. (2014b), Bridges et al. (2014), Mésonnier and Monks (2015), Aiyar et al. (2016), 
Labonne and Lamé (2018) and Imbierowicz et al. (2018), who use similar policy experiments in the UK, EU and Denmark. However, these authors also mainly focus on the impact of changes in required capital ratios on bank balance sheets and aggregate bank lending. In contrast to these papers, we can also study the bank-firm-level granting of credit using a credit register.

In this respect, we follow Jiménez et al. (2017) who use a credit register to study the impact on the supply of credit of the singular introduction and subsequent modifications of one macro-prudential policy, i.e., the dynamic provisioning in Spain, which affected all banks concurrently. Fraisse et al. (2019) and Juelsrud and Wold (2019) similarly focus on a one-off change in capital requirements that affected all banks, in respectively France and Norway, during the most recent crisis, while Auer and Ongena (2016) study the compositional changes in banks' supply of credit using variation in their holdings of residential mortgages on which extra capital requirements were uniformly imposed by the countercyclical capital buffer introduced in Switzerland in 2012. Gropp et al. (2018) analyze how the outcome of the capital exercise conducted by the European Banking Authority in 2011 affect banks' balance sheets, syndicate lending and firm outcomes. Finally, Célérier et al. (2016) study the effect of tax reforms abroad (in particular in Italy and Belgium) and find that the resulting decrease in the cost of equity leads banks to raise their equity ratio, and to concurrently expand their balance sheets by increasing the amount of credit supplied in Germany.

The main differences with the latter literature originate from studying many changes in individual bank capital ratios over time and using multiple micro-datasets. Our contribution is thus that we can comprehensively study policy experiments that change individual required and actual bank capital ratios. We study their impact on bank balance sheets and credit granting, and study various sources of heterogeneity in this relationship due to monetary, firm and bank conditions.

The rest of the paper proceeds as follows. Section 2 discusses the process that leads to Pillar 2 capital requirements. In Section 3, we present the methodology and document the relationship between capital (requirements) and the supply of credit to firms. Section 4 consists of three subsections documenting the channels through which the identified relationship works. In particular, we examine the heterogeneous impact of required capital on credit supply due to differences in banks' cost of equity, banks' business models and firms' impact on risk-weighted assets. In Section 5, we present the outcome of many extensions and robustness checks. In particular, we shed further light on the causality of the established relationships as well as analyzing potential anticipation effects 
of the policies and asymmetric responses. In Section 6, we analyze how capital requirements affect broad balance sheet categories, allowing us to assess what happens to other markets beyond lending to corporations. Section 7 concludes.

\section{Pillar 2 capital requirements}

We focus on an interesting period between the adoption of the Twin Peaks supervisory model in April 2011 and the start of the Single Supervisory Mechanism in November 2014. During that period, the micro-prudential supervision of banks active in Belgium was the responsibility of the National Bank of Belgium (NBB). Hence, during that time, the micro- and macro-prudential supervision of the Belgian financial sector was integrated within one single institution, with the aim

of maintaining and improving both the micro- and macroeconomic resilience. Prior to April 2011, supervision was one of the responsibilities of the Banking, Finance and Insurance Commission. Post-2014, with the introduction of the Single Supervisory Mechanism, the supervision of significant banks has been centralized at the European Central Bank, whereas that of less significant institutions is still the responsibility of the NBB.

One of the micro-prudential instruments in the NBB's toolbox to maintain or achieve financial stability are bank-specific capital requirements (Pillar 2 capital requirements under Basel II). The Pillar 2 regulatory capital requirements are the outcome of a (usually) yearly Supervisory Review and Evaluation Procedure (henceforth, SREP or the evaluation process) for individual banks operating in Belgium. The evaluation process is a continuous procedure that results in a Tier 1 common equity capital requirement that is privately communicated to the bank by the end of a given year and becomes effective and binding as of January 1st of the following year. The last capital requirements that are still set by the NBB (rather than the Single Supervisory Mechanism) are communicated in December 2014, thus implying that our sample period ends in 2015. Figure 1 provides a graphical presentation of the evaluation process that involves multiple inputs to assess the risk profile of an institution and to determine appropriate supervisory actions.

\section{Insert Figure 1 around here}

Inputs in the evaluation process are, among other things, internal bank performance reports, reports 
from external and internal auditors, the credit institution's Internal Capital Adequacy Assessment Process, as well as information obtained via contacts with the institutions and other supervisors (via so-called supervisory colleges). Quantitative and qualitative assessment of risks as well as their management by institutions are an essential component of the SREP. The structured analysis of risks under the SREP is provided by the score-carding system, covering both a quantitative assessment of the level of risks and qualitative aspects of the quality of management control. Together with the review of the Internal Capital Adequacy Assessment Process and stress tests, the output of the score-carding process feeds into the overall risk assessment of the institution and forms the basis on which supervisory actions will be determined and planned. Through this process, the final capital decision, which must be approved by the NBB Board, takes into consideration a full range of risks. As micro-prudential supervisor, the NBB was, through the evaluation process, responsible for setting the Pillar 2 capital requirements for the banks under its supervision. Up until 2014, this involved all banks with a Belgian banking license, both domestic banks as well as subsidiaries of foreign banks operating in Belgium. On the basis of the evaluation process, the NBB sets capital requirements for all relevant legal entities, including both capital requirements at group level as well as at the level of individual banks.

From the micro-prudential supervisor, we obtain information on both the required capital ratio as well as the actual capital ratio at individual bank level. More specifically, we focus in this paper on the following two variables. First, Previous quarter actual capital ratio captures the ratio of Tier 1 common equity to risk-weighted assets. It captures the amount of regulatory capital in relation to risk-weighted assets at the beginning of the quarter over which loan growth is measured. Second, Previous quarter required capital ratio is the required capital ratio (Pillar 2 capital requirement). The banks are informed of the required capital ratio at the end of the last quarter of the preceding year and it is binding for the entire upcoming year. Hence, for all quarters in a given year $Y$, the variable Previous quarter required capital ratio coincides with the announced required ratio in the last quarter of year $Y-1$. The difference between these two measures is the capital buffer. ${ }^{3}$

Crucial for the analysis is that the supervisor has discretion in setting the Pillar 2 capital requirements and that the decision is exogenous with respect to the risks covered by Pillar 1 as well as past or future lending growth. Moreover, in the analysis, because of the sets of fixed effects, we only

\footnotetext{
${ }^{3}$ Banks do not have much room to tweak or manipulate these capital requirements. While regulatory arbitrage cannot necessarily be avoided, if observed (for instance by 'playing' with diversification or aggregation procedures), the supervisor can address this in its Pillar 2 add-ons.
} 
exploit the within-bank variation as well as the within-time-period variation to avoid concerns that time-invariant bank-specific characteristics or economic conditions jointly affect lending decisions as well as the capital requirements. Moreover, in the robustness section, we will conduct further analyses documenting that all established relationships can be interpreted in a causal sense.

\section{Insert Table 1 around here}

Summary statistics on these measures are provided in Table 1. Over the sample period, the average required capital ratio is $11.0 \%$ of risk-weighted assets (RWA), with a standard deviation of $1.9 \%$. The actual risk-weighted capital ratio has a mean of $14.9 \%$ of and a standard deviation of $3.8 \%$. Hence, both the mean and the dispersion in actual capital ratios are higher than those of the required capital ratios. The average capital buffer, the difference between the actual and required capital ratio, equals $3.9 \%$ of RWA, indicating that the average bank has a relatively large cushion. ${ }^{4}$ The range of the variation in (required) capital across banks corresponds with the statistics reported by Aiyar et al. (2014b) who have information on the UK for the period 1998-2007. Using a longer time span and a larger sample of banks, they find that the minimum required capital ratio was $8 \%$, its standard deviation was $2.2 \%$, and its maximum was $23 \%$ of risk-weighted assets.

In panel B of Table 1, we report summary statistics on some bank characteristics for those banks for which we have information about the regulatory capital ratio. In each of these characteristics, there is sufficient variation across banks and over time. The average bank generates a low but stable quarterly return on equity, has a loan to total assets ratio of $53.4 \%$, relies strongly on retail deposits (the average share of demand and savings deposits is $80 \%$ ) and $61 \%$ of its income stems from interest-generating activities. During the sample period, the Belgian economy and banking sector experienced low, but stable growth.

The bank capital requirements are set for domestic banks as well as for subsidiaries of foreign banks. The NBB has no supervisory authority over branches of foreign banks and hence these are

\footnotetext{
4 The average capital buffer is substantially high. Banks are careful and keep sufficient voluntary (management) buffers to avoid a breach. Also, supervisors do not necessarily wait for a breach to intervene and voice concerns on low management buffers ahead of actual problems. However, in case of a breach of the requirements several actions can be taken. First, a breach implies a thorough discussion with the supervisor on plans to restore, in the shortest time possible, the capital base to satisfy the capital requirement. Second, in the short run, this may imply several actions including a prohibition to distribute dividends and interventions in remunerations of the leading management. Finally, in the event of prolonged or structural breach, the supervisor can assign external managers to restructure the bank.
} 
not included in our sample. In Table A1 of the appendix, we provide detailed information on the number of borrowers, the total amount of credit granted and aggregate total bank assets for the group of banks for which we do and do not have information on regulatory capital. We also report the total number of banks in each group. For three banks, the information on required capital is not available for the first year of our analysis (2013). While the number of banks in each group is similar (in 2014 and 2015), note that the sample of banks with regulatory data contains the important banks. In each quarter of 2014 and 2015, the SREP-sample banks cover at least 95\% of all firm-bank relationships, total volume of credit granted and total banking assets in Belgium. Note also that the share of corporate lending in total assets is lower in the group of foreign bank branches (no Pillar 2 data available) compared to the group of Belgian banks or foreign subsidiaries (for which Pillar 2 requirements are available).

\section{$3 \quad$ Regulatory capital and corporate credit supply}

\subsection{Measuring credit conditions}

To identify the causal impact of capital requirements on corporate credit supply, we make use of information from the Corporate Credit Register held by the National Bank of Belgium. The Corporate Credit Register contains information on credit granted by credit institutions to legal entities (i.e., enterprises). Each month, a credit institution needs to provide information to the Credit Register on all debtors. We extract all available credit data at the bank-firm-quarter level but only retain non-financial corporations (NFCs). This implies that we filter out (i) borrowers from the financial or insurance sector (in line with most other corporate finance studies) and (ii) borrowers active in public administration, education or household activities (as these are not NFCs, nor do they file balance sheets). We use quarterly information rather than monthly as this matches the frequency of the bank balance sheet data and information on banks' capital ratios.

Using this database, we construct several variables that vary at the bank-firm-quarter level and provide an indication of credit conditions at both the intensive and extensive margin. Summary statistics of these measures are reported in panel A of Table 2. First of all, we compute quarterly authorized credit growth at the bank-firm level (Credit growth). This is the quarterly change in 
the natural logarithm of authorized credit at the bank-firm level. More importantly, we define credit as the total amount of authorized (or granted) loans. The average growth in authorized credit granted is slightly negative at $-2.9 \%$, mainly due to amortizations. There is substantial cross-sectional variation, with a standard deviation of $23.7 \%$, indicating that some firms witness substantial drops in their credit exposures (due to outright cuts or lower likelihood of renewals or roll-overs), whereas other bank-firm exposures grow substantially. However, less than $10 \%$ of the bank-firm credit exposures strictly increase over the course of a quarter.

\section{Insert Table 2 around here}

Second, we create a dummy Large drop in credit which equals one if the firm's credit growth is in the lowest quartile of the credit growth distribution of all the bank-firm observations in the sample. The quarterly growth rate of authorized credit at the 25 th percentile is $-6.15 \%$, whereas the average in this lowest quartile is $-24 \%$ (neither statistics are reported in Table 2). This variable proxies for authorized credit volumes that have been reduced substantially, or matured without having been rolled over. The two aforementioned measures provide information on the intensive margin of bank-firm relationships. That is, they provide an indication of banks' willingness to extend credit

to incumbent borrowers. Our third measure is a dummy New relationships that equals one if a firm has credit granted from a bank at time $t$, but was not borrowing from that bank at the end of the previous year (when the new required capital ratio is communicated). in doing so, we will not only test the impact of capital requirements on actual loan growth, but also the impact on banks' propensity to generate new bank-firm credit relationships (and thus the extensive margin of credit provision). On average over all quarters, $2.2 \%$ of bank-firm relationships are newly established relationships.

The three aforementioned measures are based on authorized or granted amounts of credit. For credit lines, this implies that we look at the total amount of credit that is available, and not at the portion that is taken up by the borrower. In this way, we make sure that any changes in credit are not driven by a sudden draw-down of a credit line by a borrower (which is an indication of credit demand rather than credit supply). However, as a fourth indicator, we also compute the Utilization rate of credit, which is the ratio of the utilized amount at the bank-firm level over the authorized amount at the bank-firm level, measured at time $t$. The average utilization rate is 
$66.7 \%$, but there is huge variation across bank-firm pairs. Indeed, the standard deviation of the utilization rate is $39.1 \%$.

Fifth, we also focus on term loans only, for which there is no discrepancy between authorized and utilized amounts. Term loans are either fixed-term credit, non-residential mortgage loans or nonmortgage instalment loans. The average (and median) Term credit growth (-6.7\%) is much lower compared to the average credit growth of all credit $(-2.9 \%)$, precisely because of the amortization schemes of the former. Finally, our sixth measure of credit conditions is the Collateralization rate, which is the ratio of pledged collateral by a firm to a bank (for all its credit) over the total amount of authorized credit at the bank-firm level. On average, $61.6 \%$ of the granted credit amount is covered by pledged collateral, although the median is much lower (46.3\%) as many firms pledge more collateral than the borrowed amount (or the outstanding amount).

\subsection{Methodology and hypotheses}

The empirical specification used to document the relationship between (required) regulatory capital and the six credit variables is the following:

$$
\begin{aligned}
\text { Credit condition (Quarterly })_{b, f, t}= & \beta_{1} * \text { Required capital } \text { ratio }_{b, t-1} \\
& +\beta_{2} * \text { Previous year required capital ratio }{ }_{b, t-5} \\
& +\beta_{3} * \text { Actual capital ratio }{ }_{b, t-1} \\
& +\beta_{4} * \text { Previous year actual capital ratio } \text { rat }_{b, t} \\
& +\gamma * \text { Bank controls }_{b, t-1}+\nu_{b}+\nu_{f, t}+\epsilon_{b, f, t}
\end{aligned}
$$

The trio $(b, f, t)$ stands for bank, firm and time, where the unit of time is a quarter. $\nu_{b}$ is a bank fixed effect that controls for observed and unobserved time-invariant heterogeneity across banks such as e.g., ownership structure or managerial quality. $\nu_{f, t}$ is a firm $\mathrm{x}$ time fixed effect that enables us to analyze the change in credit availability to the same firm at the same time by banks with different regulatory capital ratios. In doing so, we control for observed and unobserved time-varying firm heterogeneity in loan demand, quality and risk; an empirical technique pioneered by Khwaja and Mian (2008). Finally, $\epsilon_{b, f, t}$ is a zero-mean random noise component. The standard errors are clustered at bank level. 
It is crucial for the analysis that the supervisor has discretion in setting the Pillar 2 capital requirements and that the decision is exogenous with respect to the risks covered by Pillar 1 as well as past or future lending growth. Moreover, in the analysis, because of the sets of fixed effects, we only exploit the within-bank variation as well as the within-time-period variation to avoid concerns that time-invariant bank-specific characteristics or economic conditions jointly affect lending decisions as well as the capital requirements. Moreover, in the robustness section, we will conduct further analyses documenting that all established relationships can be interpreted in a causal sense.

There are four independent variables of interest based on the regulatory capital data. They are: Required capital ratio $_{b, t-1}$, Previous year required capital ratio ${ }_{b, t-5}$, Actual capital ratio ${ }_{b, t-1}$ and Previous year actual capital ratio $_{b, t-5}$. Besides the one-quarter lagged (required) capital ratio, we also include the previous year required capital ratio, Previous year required capital ratio ${ }_{b, t-5}$, as the impact of capital requirements may take time to have effect. Previous year actual capital ratio $b_{b-t-5}$ is the one-year lagged actual capital ratio, which is included in the specification for reasons of analogy with required capital.

First of all, the main coefficients of interest are $\beta_{1}$ and $\beta_{3}$. Our first two hypotheses test whether required and/or actual capital ratios affect credit conditions. They are: H1a: $\beta_{1}=0$ and H1b: $\beta_{3}=0$. Second, besides individual significance of coefficients, we are also interested in three different joint hypotheses. First, the effect of an increase in required capital, ceteris paribus (and hence holding the actual capital ratio constant), is reflected in coefficient $\beta_{1}$. Such a situation, in which a bank's actual capital ratio does not react to an increase in requirements leads to a reduction in the capital buffer. If banks were to simultaneously also change their actual capital ratio, to restore the buffer, then the effect on credit supply is given by $\beta_{1}+\beta_{3}$. We will thus also test whether the impact of changes in regulatory capital requirements, when banks hold their buffer constant, is significantly different from zero $\left(\mathrm{H} 2: \beta_{1}+\beta_{3}=0\right)$. Note that the boundaries of the interval $\left[\beta_{1}, \beta_{1}+\beta_{3}\right]$ correspond to no adjustment and complete adjustment of the actual capital ratio in response to a regulatory change. In all cases where the buffer is only partially restored, the estimated economic effect will be in between this interval.

Third, we also test whether or not the sum of the coefficients on the required and the previous year required capital ratio is significantly different from zero (that is H3a: $\beta_{1}+\beta_{2}=0$ ). Likewise, we test whether or not the sum of the coefficients on the actual and the previous year actual capital 
ratio is significantly different from zero. That is, we test hypothesis H3b: $\beta_{3}+\beta_{4}=0$, to analyze whether the joint impact of current and lagged required capital is significantly different from zero. The latter two tests serve the purpose of testing whether there is a long-lasting impact of capital requirements or whether there is a reversal (e.g., because of initial overshooting).

\begin{tabular}{|c|c|c|}
\hline \multicolumn{3}{|r|}{ Summary of the baseline hypotheses } \\
\hline H1a & $\beta_{1}=0$ & Does the required capital ratio affect credit conditions? \\
\hline $\mathrm{H} 1 \mathrm{~b}$ & $\beta_{3}=0$ & Does the actual capital ratio affect credit conditions? \\
\hline $\mathrm{H} 2$ & $\beta_{1}+\beta_{3}=0$ & $\begin{array}{l}\text { Does the required capital ratio affect credit conditions, when banks hold } \\
\text { the capital buffer constant? }\end{array}$ \\
\hline H3a & $\beta_{1}+\beta_{2}=0$ & Is there is a long-lasting impact of required capital on credit conditions? \\
\hline $\mathrm{H} 3 \mathrm{~b}$ & $\beta_{3}+\beta_{4}=0$ & Is there is a long-lasting impact of actual capital on credit conditions? \\
\hline
\end{tabular}

The vector Bank controls $_{b, t-1}$ consists of the following variables: the natural logarithm of total assets, quarterly growth in common equity, quarterly growth in deposits, quarterly growth in total assets and quarterly return on equity. All bank variables have been lagged one quarter such that they are in principle predetermined with respect to next quarter's credit growth at the bank-firm level. In this set of controls, we also include one that varies at the bank-firm level, which is a bank-firm specific measure of credit risk (as in Aiyar et al. (2016)). In the credit register, banks provide information on their assessment of the probability that the firm will default during the ensuing year. This assessment is at the borrower level, rather than the loan (category) level, and is updated every month. We include this measure of ex-ante borrower quality. Importantly, note that it varies at the bank-firm-time level.

Four issues on the specification are worth emphasizing. First, Equation 1 is the most flexible specification which can be rewritten in terms of a model that (i) includes the buffer and the required capital ratio, (ii) the buffer and the actual capital ratio, or (iii) changes in the buffer or changes in the actual and required capital ratio. Note that a model with only the buffer would imply that $\beta_{1}=-\beta_{3}$, which is rejected by the data.

Second, prior to running the main regression, we run auxiliary regressions to analyze the scope for collinearity due to correlation between the actual and required capital ratio and/or correlation between the current and lagged values. Variance inflation factors (VIFs) are low and range between 
1.43 for the required capital ratio and 1.75 for the actual capital ratio, with values in between for the previous year actual and required capital ratio. These VIFs are sufficiently low to give no concern about possible consequences of collinearity.

Third, the choice of the lag structure is not determined by a statistical test but is driven by the nature of the required capital data and the frequency of the analysis (quarterly). Actual capital and all other variables vary at the quarterly level, but the required capital ratio is fixed for a whole year. We therefore only include the lags $t-1$ and $t-5$ in the specification, which means including the current required capital ratio and the previous value of the required capital ratio (i.e., the one that applied in the previous calendar year). Jointly including all intermediate lags would lead to spurious results due to highly correlated variables (because of the persistence) and, accordingly, high VIFs. ${ }^{5}$ Given the staleness of the intermediate lags vis-à-vis the current or one-year lagged values and the higher VIFs, we prefer the parsimony of Equation 1.

Fourth, two of the dependent variables are binary indicators ('Large drop' and 'New bank-firm relationships'). In the absence of any fixed effects, a binary dependent variable would imply using a logit or probit model. However, in the presence of many fixed effects (firm*time FE and bank FE), such non-linear models suffer from an incidental parameter problem. Therefore, we follow common practice (see, e.g., Khwaja and Mian (2008)) and use a linear probability model that allows for (multiple sets of) high-dimensional fixed effects.

\subsection{Baseline results: loan level}

The results of estimating Equation 1 for the six different dependent variables that capture various dimensions of credit provision are reported in Table 3.

\section{Insert Table 3 around here}

Four general findings stand out. First, ceteris paribus, focusing on the estimated $\beta_{1}$ coefficients in the different columns, we see that raising the required capital ratio reduces the supply of credit on

5 The required capital ratio at the intermediate lags is either identical to the current required capital ratio or one-year lagged required capital ratio. For example, for observations in the third quarter, the values of required capital at $t$ - 2 will be the same as on $t$ and $t-1$. The value on $t$ - 3 (referring to the fourth quarter of the previous year) will be the same as the one-year lagged required capital ratio. 
the intensive and extensive margin. We thus reject hypothesis H1a: $\beta_{1}=0$. Holding constant the level of actual capital (and hence a shrinking buffer), a one standard deviation increase in required capital $(1.5 \mathrm{pp})$ leads to a $0.19 \mathrm{pp}$ decrease in the quarterly credit growth rate. Put differently, the same firm borrowing from two banks that differ only in the level of required capital will see slightly lower credit growth from the bank with the higher required capital ratio. The economic significance of this effect is nevertheless moderate. In line with this finding, banks with higher capital requirements are less likely to start new bank-firm relationships, and again the effect is statistically significant, but economically moderate (column 3). The tightening of the credit supply by banks with a higher capital requirement implies a higher utilization rate by the affected firms. The ratio of utilized (or drawn) credit to authorized credit increases. Note also that the coefficient on required capital is 2.5 times larger when only focusing on term loans (fifth column), implying an economically larger effect for term loans compared to all credit exposures. A one standard deviation increase in required capital leads to an effect of $0.5 \mathrm{pp}$ on term credit growth. There is no significant effect of capital requirements on the collateralization rate.

Second, an increase in actual capital holdings, holding constant the required capital ratio (and thus an increase in the buffer) also reduces the supply of credit. We thus also reject hypothesis H1b: $\beta_{3}=0$. Whenever significant, $\beta_{3}$ has a similar sign to $\beta_{1}$. The economic effects are again moderate and of comparable magnitude to an increase in the required capital ratio.

Third, combining the two aforementioned situations, i.e., an increase in both the required and actual capital ratios (e.g., a situation where a bank is preserving its capital buffer in response to an increase in the capital requirement), leads to a stronger contraction of credit supply. We report the sum of these two coefficients $\left(\beta_{1}+\beta_{3}\right)$ in the first row of the lower panel and the $\mathrm{p}$-value of testing hypothesis two $\left(\mathrm{H} 2: \beta_{1}+\beta_{3}=0\right)$ in the second row of the lower panel. Except in the last column, we can reject the hypothesis that a joint and equal increase in required and actual capital ratios (thus holding constant the regulatory buffer) does not affect credit supply. A one standard deviation increase in required capital (1.5 pp) combined with a $1.5 \mathrm{pp}$ increase in the actual capital ratio leads to (i) a $0.40 \mathrm{pp}$ decrease in the quarterly credit growth rate $(-0.80 \mathrm{pp}$ for term credit growth), (ii) a $1.14 \mathrm{pp}$ increase in the probability of experiencing a large drop and (iii) a $1.11 \mathrm{pp}$ decrease in the probability of starting a new bank-firm relationship. Moreover, the utilization rate of credit goes up with $0.72 \mathrm{pp}$ in such a case. 
Fourth, the effect of changes in the required capital ratio is long-lasting. That is, the required capital ratio set in the previous year also has a significant impact on the growth of credit $\left(\beta_{2}\right.$ is significant in four specifications), whereas the previous year actual capital ratio does not have a significant impact on credit supply ( $\beta_{4}$ is never significant). In the next to last row of the table, the p-value of a significance test of the sum of the effects of the current and previous year required capital ratio often hints at statistical significant effects of the joint impact. H3a: $\beta_{1}+\beta_{2}=0$ is rejected in half of the cases, whereas $\mathrm{H} 3 \mathrm{~b}: \beta_{3}+\beta_{4}=0$ is never rejected.

In sum, we do find statistically significant effects of bank capital requirements on the provision of credit both at the intensive and extensive margins. However, the effects are moderate in economic magnitude and the methodology only enables an assessment of the differential credit supply effects of capital requirements. Therefore, in the next subsection, we test whether higher capital requirements are effectively leading to higher credit constraints at the firm level. Put differently, we will test whether firms can set off the reduction in credit from banks with higher capital requirements with credit from banks with lower capital requirements or with credit from branches of foreign banks that are not supervised by the National Bank of Belgium.

\subsection{Aggregate results: firm level}

The results in Table 3 show that firms will receive less credit from banks with higher capital requirements. These loan-level results imply a drop in credit supply, however, the effects could be mitigated if firms can obtain credit from less affected banks or from foreign branches. To address the scope for mitigation, we conduct some additional analyses in line with the approach followed by Khwaja and Mian (2008) and Jiménez et al. (2017) and assess an aggregate or macro effect of capital requirements using firm-level estimations.

Therefore, we collapse the data to the firm-time level. The dependent variable is now the log change in credit received by a firm from all banks for which we know the SREP capital requirement. The credit obtained after the shock can be from both "current" and "non-current" banks (that did not lend to the firm prior to the shock). The bank-specific variables (and thus also the capital requirements) are weighted averages, weighing each bank value by its loan volume to the firm over total bank loans taken by this firm. As this is a regression at the firm level, we can no longer include a firm x time fixed effect. To control for firm demand, we include the estimate firm $\mathrm{x}$ time 
fixed effect from Equation 1. We also include a weighted average of the estimated bank fixed effect, weighing each bank fixed effect by its loan volume to the firm over total bank loans taken out by this firm. The goal of this first additional regression at the firm level is to analyze whether firms can offset the reduced credit supply from banks with a higher capital requirement with credit from banks with a lower capital requirement. The results reported in the first column of Table 4 show that this is not the case. Indeed, the coefficient on required capital is still negative and significant.

\section{Insert Table 4 around here}

In the Belgian credit market, there are also branches of foreign banks active which are not subject to supervision by the NBB and are thus not subject to Pillar 2 requirements by the NBB. For these branches, we do not know whether or not their home supervisor imposes Pillar 2 requirements. If these branches' parent companies were to face lenient capital requirements, then they could substitute the loss of credit faced by firms because of more tightly regulated Belgian banks. In order to test that, we now use, as a dependent variable, the log change in credit received by a firm from all banks (including foreign branches) active in Belgium. In the second column of Table 4, we still find a negative and significant effect of required capital. Borrowers, who are receiving less credit from domestic banks with higher capital requirements, cannot set off this by borrowing either from domestic banks with a lower requirement or by borrowing from foreign branches.

In the third column, we use as dependent variable the growth rate of credit provided to a firm by foreign branches (not supervised by the NBB). Note that this is a substantially smaller sample. Only a small fraction of firms $(3.6 \%)$ borrow from both a regulated bank and a foreign branch. Firms seem to receive more credit from outside branches if their domestic banks face higher capital requirements $\left(\beta_{1}\right.$ is positive), but the coefficient is insignificant. Yet, while the credit loss cannot be offset, we do find a compositional effect: the share of credit provided by NBB-supervised banks (in total credit received by the firm) is lower for firms borrowing from banks with higher capital requirements (last column).

In sum, we find that tighter capital requirements lead to aggregate negative effects on credit supply. Firms cannot substitute the reduction in credit by borrowing more from banks with lower capital requirements or from foreign branches operating in Belgium. This lack of substitution by foreign branches could be either due to the small role they play in the credit provision to Belgian firms 
(see Table A1 of the online appendix), or because these foreign branches might themselves also face capital requirements of a similar magnitude (which we cannot observe as they would be set by a foreign regulator).

\section{Regulatory capital and credit supply: documenting channels}

So far, we have focused on the average effect of (required) capital on bank credit supply. However, this relationship need not be homogeneous, but may vary with bank or firm characteristics. First of all, in subsection 4.1, we test the hypothesis that frictions or costs associated with raising equity affect the extent to which capital requirements impact credit supply. Subsequently, we test the hypothesis that bank business models impact the way capital requirements restrict credit supply (Subsection 4.2). Finally, in Subsection 4.3, we provide some insight into which firms will be affected more by banks' goal to reduce risk-weighted assets in response to higher capital requirements. We thus test the hypothesis that banks faced with higher capital requirements treat all borrowers equally or not.

\subsection{Factors affecting banks' cost of capital}

The Modigliani and Miller paradigm stipulates that a firm's capital structure is irrelevant for its operating decisions. In the banking context, this would imply, for instance, that the rate a bank charges on its loans, as well as the volume of loans should be independent of its funding structure, including its leverage and capital ratio. However, the real world may deviate in various ways from the theoretical Modigliani-Miller set-up (see Kashyap et al. (2010) for an overview). Consequently, in the short run, a phasing of higher capital requirements might prompt banks to meet them by contracting credit supply (lower volume and higher lending rates), rather than issuing equity or increasing retained earnings though reductions in dividends. Unfortunately, we cannot directly test deviations from the Modigliani-Miller world. However, we will test them indirectly by analyzing whether the established negative relationship between regulatory capital ratios and credit supply to corporations is less pronounced for banks whose equity financing is relatively cheaper, or that have less need to adjust equity. 
First of all, we assess whether the relationship established in Section 3 varies with monetary policy. The monetary policy stance directly affects the cost of and access to funding by banks as well as the market conditions for raising equity. Note that the period under analysis is an exceptional period in terms of monetary policy conditions and interventions, affecting both credit supply as well as banks' characteristics. The European Central Bank has been trying to stimulate bank lending with a series of unconventional monetary policy measures. While we have been controlling for monetary policy (and other macro-economic conditions) by means of time-fixed effects,(un)conventional monetary policy may also interact with (micro)prudential policy in influencing banks' lending behavior. ${ }^{6}$ To that end, we introduce an interaction term between the required capital ratio and the quarterly growth in the balance sheet of the European Central Bank (ECB). The growth of the ECB's balance sheet is used as a proxy for the monetary policy stance, as both conventional and unconventional monetary policy may lead to change in the volume of assets held by the ECB.

Subsequently, we test the conjecture whether the impact of changes in required capital on the supply of credit to corporations varies with bank-specific characteristics affecting banks' cost of equity. We assume that the negative relationship between the required capital ratio and credit supply should be more pronounced for small and risky banks, given that, in general, the cost of capital is lower for larger and safer banks (Kashyap et al. (2010), Baker and Wurgler (2015), and Gandhi and Lustig (2015)). In the tests, we include the natural logarithm of total assets (bank size) and the ratio of loan loss provisions to total assets (risk), to test the aforementioned conjectures. Furthermore, the cost of capital is lower for more profitable banks. Profitable banks have a larger franchise value, which reduces their incentives for excessive risk-taking. Moreover, they have more scope for internal capital generation by retaining earnings and, hence, can manage capital passively (as opposed to active management via raising equity externally, see e.g., De Jonghe and Öztekin (2015)). Hence, we expect the impact of required capital on credit supply to be weaker for banks with a higher return-on-equity (proxy for bank profitability). Finally, banks with higher past equity growth have built up some financial slack and have been able to time the market/regulator. This may not necessarily affect the cost of raising equity, but reduces the need or urgency to do so. We thus expect that the negative relationship is less pronounced for these banks.

We test the aforementioned hypotheses using the following regression framework:

${ }^{6}$ Theoretical models on the interaction of capital requirements and monetary policy have been developed by e.g., Angeloni and Faia (2013), Angelini et al. (2014) and Du and Miles (2014), while the relationship has been empirically tested by Aiyar et al. (2016). 


$$
\begin{aligned}
& \text { Credit growth }_{b, f, t}=\left(\beta_{1}+\beta_{1}^{M P} * \text { Monetary pol }_{t-1}+\beta_{1}^{B C} * \text { Bank }_{\text {char }_{b, t-1}}\right) * \text { Required capital ratio } \\
& b, t-1 \\
&+\beta_{2} * \text { Previous year required capital ratio } \\
&+\beta_{b, t-5} * \beta_{3} * \text { Previous year actual capital } \text { ratio }_{b, t-5}+\gamma * \text { Bank controls } \text { ratio }_{b, t-1} \\
&+\nu_{b}+\nu_{f, t}+\epsilon_{b, f, t}
\end{aligned}
$$

The specification is identical to Equation 1, except for the interaction coefficients $\beta_{1}^{M P}$ and $\beta_{1}^{B C}$, which stand for the interactive effect on credit growth of the required capital ratio and, respectively, monetary policy or a bank characteristic on credit growth. The results of these regressions are reported in Table 5. The monetary policy indicator and the bank characteristics have been standardized to facilitate comparison of their economic magnitudes.

In the first column, we find that monetary policy affects the relationship between capital requirements and credit supply. The interaction term is negative and significant, implying that an expansion of the European Central Bank's balance sheet will have a weaker impact on credit supply for banks with higher capital requirements. The results in the first column thus indicate that there might be a trade-off between (micro-)prudential capital requirements and monetary policy. An alternative way of interpreting the negative interaction coefficient is that tightening capital requirements during expansionary monetary policy periods is more detrimental for credit supply, compared to a similar increase during monetary tightening. A one standard deviation increase in the growth rate of the ECB's balance sheet raises the point estimate of the impact of required capital on credit supply from $-0.201\left(=\hat{\beta}_{1}\right)$ to $-0.362\left(=\hat{\beta}_{1}+\hat{\beta}_{1}{ }^{M P}\right)$. Likewise, a one standard deviation decrease in the growth rate of the ECB's balance sheet results in an almost zero impact of required capital on credit supply $\left(\hat{\beta}_{1}-\hat{\beta}_{1}^{M P}=-0.04\right.$, to be precise). While this result is in contrast to our initial hypothesis, it may be rationalized by the zero lower bound and the pressure that these unconventional policies put on banks' profit margins.

\section{Insert Table 5 around here}

In subsequent columns, we add an interaction term for the required capital ratio and the $\log$ of total assets (size), loan loss provisioning ratio (risk measure), return on equity (scope for earnings 
retention), growth in common equity (market timing) and a dummy that is one for banks in the lowest quartile of the capital buffer distribution (capital buffer=actual-required). This coincides with a buffer of less than 3 percent. Each interaction term enters as a one-quarter lag. The point estimates of the interaction terms provide support for each of the aforementioned hypotheses. First of all, firms are more shielded from a reduction in lending due to higher capital requirements at larger banks. ${ }^{7}$ We also find that more risky banks reduce lending to a larger extent, in response to an increase in required capital ${ }^{8}$. This provides support for the hypothesis that the cost of equity (which is higher for riskier banks) is the constraining factor leading to negative effects of capital on lending.

Second, more profitable banks constrain credit supply less in response to higher capital requirements. More profitable banks can use passive capital management (earnings retention) to restore their capital buffers and can protect their borrowers more. Third, we also find that the negative impact is reduced for banks that expanded their capital buffer in the previous period. Indeed, the interaction term on equity growth is positive and significant. Finally, in the last column, we find that banks with a smaller buffer reduce credit supply less for a given increase in required capital, compared to banks with a larger buffer. A possible explanation for this finding might be that banks with a low buffer that face a higher requirement may act via increasing equity. By relying on equity issuance rather than asset-shrinking, the bank would be able to more swiftly restore the buffer (or even increase it). In contrast, when the buffer is large, banks may opt for a more gradual restoration of its buffer (when requirements increase) by lowering credit growth.

What do these point estimates imply in economic terms? From an economic point of view, the obtained coefficients imply that a $1 \mathrm{pp}$ increase in required capital reduces credit supply by $0.24 \mathrm{pp}$ for small banks (one standard deviation below the mean, $\hat{\beta}_{1}-\hat{\beta}_{1}^{B C}$ ), and only $0.125 \mathrm{pp}$ for large banks (one standard deviation above the mean, $\hat{\beta}_{1}+\hat{\beta}_{1}^{B C}$ ). The same firm's credit supply is reduced by almost twice as much at small banks facing a higher capital requirement than at large banks facing exactly the same capital requirement increase (in the same quarter). The impact of heterogeneity in credit risk across banks is of similar economic magnitude. The effects are larger, in economic magnitude, when looking at high and low profits (losses) or fast and slow equity growth (as the

7 Aiyar et al. (2016) also find a positive interaction effect, though it is statistically insignificant.

${ }^{8}$ Our measure of credit risk, i.e., the loan loss provisioning ratio, is an indicator of the quality of the existing loan portfolio. Our finding is in line with the theoretical prediction of Bahaj et al. (2016) that lending is less sensitive to a change in capital requirements when legacy assets are healthy. 
standardized point estimates are larger). The implied effect of a $1 \mathrm{pp}$ increase in required capital for low-profit banks (one standard deviation below the mean) is $-0.313 \mathrm{pp}$, whereas it is $0.091 \mathrm{pp}$ for highly profitable banks (mean plus one standard deviation). Concerning equity growth, we find similar economic effects of fast equity growth, as for highly profitable banks. Turning to the last column, in economic terms, the impact of higher capital requirements on credit supply is almost non-existent for banks with a buffer belonging to the lowest quartile of the distribution.

\subsection{Factors affecting banks' business model}

All banks in the sample are commercial banks. Yet, commercial banks may have different business models. The specific hypothesis being tested in this subsection is that banks with features associated with a wholesale commercial bank business model transmit higher capital requirements less into credit supply than retail banks. The latter have less flexible sources of funding and less diversification alternatives. Therefore, when confronted with higher capital requirements, they are more constrained in their actions and will squeeze borrowers more. In our analysis, we do not classify banks according to a business model typology ${ }^{9}$, but rather investigate the role of variables associated with retail versus wholesale commercial bank types. We therefore include interaction effects between required capital and four characteristics featured in banks' business models. These four characteristics are: bank asset growth, the reliance on stable deposit funding, the importance of wholesale and interbank funding, and the importance of non-interest income sources. In addition to being the driving forces behind bank business model clusters, these factors have been shown to be defining characteristics of bank performance (Fahlenbrach et al., 2012). The advantage of our approach over a classification by bank types is that we can pinpoint which specific aspect could create heterogeneity (and to what extent) in the relationship between required capital and corporate credit supply.

\section{Insert Table 6 around here}

We again use Equation 2 to estimate these relationships and we report the results in Table 6 . In

${ }^{9}$ Note that a thorough business model analysis only became part of the SREP Guidelines as of 2014 (EBA/GL/2014/13) and was thus not yet in place during our sample period. Moreover, even now, there is still no consensus on which methodology to use to identify bank business models (Cernov and Urbano, 2018). 
contrast to variables related to banks' cost of financing, we hardly find any support for the hypothesis that business model characteristics matter for the transmission of capital requirements to credit supply. Heterogeneity among banks in asset growth does not affect how capital requirements affect credit supply. Furthermore, the composition of banks' funding also does not create heterogeneities in banks' responses to higher capital requirements. The interaction effect is not significant, neither for banks with more stable funding (higher share of demand and savings deposits) nor for banks with a strong reliance on interbank funding. The only significant interaction term in Table 6 is between required capital and the share of interest income in total income, which is negative and significant. Banks that are more dependent on typical intermediation income reduce credit supply more in response to tighter capital requirements. Banks with a lower share of interest income in total income seem to shield the corporate lending market and potentially curb their exposures in markets generating non-interest income. In economic terms, a bank with a high (low) reliance on interest income (one standard deviation above (below) the mean) reduces credit supply by $0.25 \mathrm{pp}$ $(0.083 \mathrm{pp})$ in response to a $1 \mathrm{pp}$ increase in capital requirements.

Comparing the results in Table 5 and Table 6 , we find that characteristics related to banks' cost of financing are a more likely source of heterogeneity in the impact on credit supply, than characteristics related to banks' business models. Hence, the channel through which bank capital requirements affect lending is through banks' financing constraints.

\subsection{Borrower heterogeneity}

Thus far, we have shown that higher capital requirements lead to lower credit supply and that banks for which the cost of capital is higher will constrain credit supply to a larger extent. To meet the higher required capital ratio, banks reduce lending to adjust their actual risk-weighted capital ratio. As not all firms are equal in terms of impact on risk-weighted assets, we should expect banks to treat borrowers differentially. In this subsection, we thus test the hypothesis that banks discriminate between borrowers in constraining credit, in response to increased capital requirements.

Cutting credit more to larger firms (ln of total assets) and riskier firms (measured by Altman $\mathrm{Z}^{10}$,

${ }^{10}$ We employ the Altman $\mathrm{Z}$ for privately held corporations, which is a linear combination of five financial ratios. More precisely, Altman $\mathrm{Z}=0.717 \times$ Working capital to total assets $+0.847 \times$ Retained earnings 
financial leverage or collateralization rate) will enable banks to adjust their volume of risk-weighted assets more swiftly. Furthermore, if banks have to cut credit, they might be less likely to cut it for firms that pay higher interest rates (cost of borrowing is measured as total financial expenses over total loans), as this protects bank profits and leaves scope for earnings retention.

Next, we also include an interaction term with firm age. The predicted sign for this variable is ambiguous because of two opposite forces. Older firms are, on the one hand, on average less risky (survivorship bias), but, on the other hand, they are larger and also have larger loans (because firms grow over the life cycle). The pairwise correlations between firm age, on the one hand, and firm size, Altman Z and financial leverage, on the other hand, are respectively, 0.36, 0.09 and -0.18 . Finally, we measure the relationship length between a bank and a firm (in months) and expect the effect to be smaller for firms with longer relationships with their banks, as these firms are less risky (stable access to financing) and pay higher interest rates (locked into their relationship). Characteristics on Belgian corporations are obtained via filings of their balance sheets and income statements to the NBB. The average firm, in our sample, is nineteen years old (standard deviation of 12), with 3,187,731 euro in assets (standard deviation is $8,909,007$ euro). The average financial leverage ratio in the sample is $26 \%$ (standard deviation is $22 \%$ ). The average Altman $\mathrm{Z}$ score is 0.83 , but has a standard deviation of 1.27 .

We estimate these interaction effects using the following specification, which is akin to Equation $(2)$ :

$$
\begin{aligned}
& \text { Credit growth }_{b, f, t}=\left(\beta_{1}+\beta_{1}^{M P} * \text { Monetary pol }_{t-1}+\beta_{1}^{F C} * \text { Firm char }_{f, t-1}\right) * \text { Required capital ratio } \\
& b, t-1 \\
&+\beta_{2} * \text { Previous year required capital ratio } \\
&+\beta_{b, t-4} * \beta_{3} * \text { Previous year actual capital } \text { ratio }_{b, t-1} \\
&+\nu_{b}+\nu_{f, t}+\epsilon_{b, f, t}
\end{aligned}
$$

The results of these regressions are reported in Table 7 . The monetary policy indicator and the firm characteristics have been standardized to facilitate comparison of their economic magnitudes. To begin with, we find that the impact of an increase in required capital on credit supply is more negative for larger firms (measured in total assets). The economic magnitude of the size effect over total assets $+3.107 \times$ EBIT over total assets $+0.42 \times$ Book value of equity to total liabilities +0.998 $\mathrm{x}$ Operating revenues over total assets. 
is large. Credit growth will be substantially lower for larger firms that borrow from banks with higher capital requirements $\left(\hat{\beta}_{1}+\hat{\beta}_{1}^{F C}=-0.159-0.243=-0.402\right)$, whereas small firms (one standard deviation below the mean) will have no (statistically) significant effect on their credit growth (the hypothesis $\beta_{1}-\beta_{1}^{F C}=0$ cannot be rejected for small firms).

\section{Insert Table 7 around here}

With respect to the risk indicators, higher values of the Altman $\mathrm{Z}$ score or pledged collateral ${ }^{11}$ indicate less risk, whereas firms with more financial leverage are riskier. The estimated coefficients thus indicate that riskier firms are penalized more in terms of lower credit supply by banks with higher capital requirements. In the absence of actual (firm-specific) risk weights, this is the best indication that banks shift their credit supply in order to reduce risk-weighted assets. The economic magnitude of the risk effects is sizeable, though smaller than the size effect (for each of the three risk characteristics). Furthermore, the interaction term with a firm's implied interest rate is positive and significant. The implied interest rate is computed as the ratio of firms' financial costs over the sum of long- and short-term loans. The negative impact of higher capital requirements on credit supply is weaker for high versus low implied interest rate firms. Firms with a one standard deviation higher (lower) cost of borrowing will have a $0.25 \mathrm{pp}(0.13 \mathrm{pp})$ reduction in credit supply in response to a $1 \mathrm{pp}$ increase in capital requirements.

We find a negative interaction effect on firm age. Note that the predicted sign was unclear as older firms are, on average, both less risky but larger. The size effect seems to dominate the risk effect as an increase in required capital leads to more constrained credit supply for older firms, relative to younger firms. In economic terms, the impact is smaller than that found in the first column, precisely because of the offsetting risk effect. While cutting lending more to larger firms enables swifter adjustment of the risk-weighted capital ratio, there might also be another reason why banks restrict credit supply more to larger and older firms, in response to higher capital requirements. Banks can simultaneously facilitate access to alternative sources of financing to larger and older firms, via debt markets or syndicated loans. Unfortunately, data availability does not permit us to investigate this conjecture in further detail.

\footnotetext{
${ }^{11}$ Pledged collateral is a dummy that is one if the ratio is in the highest quartile, and zero otherwise.
} 
Finally, the result obtained in the last column is inconsistent with the hypothesis that banks protect firms with longer relationships more than relatively new borrowers. The dummy variable called Relationship Length, which equals one for borrowers in the lowest quartile of the distribution (relationship length of 2.5 years or less) and zero otherwise, is positive and significant. In fact, the results indicate that banks even increase credit supply (in response to higher capital requirements) to their fresh borrowers at the expense of incumbent borrowers. While this finding may be counterintuitive, it could be due to other factors correlated with the length of the bank-firm relationship. Borrowers with a short relationship may be younger and smaller firms, which are growing faster and hence also need more credit.

In additional regressions, reported in Appendix A2, we analyze whether the effect is different for single-individual firms. In the absence of access to a household credit register, this would be the closest equivalent to analyze the credit supply effects on households. An important remark here is that even these single-individual firms operate under limited liability, as unlimited liability firms do not have to file any annual accounts with the Central Balance Sheet Office. We find that the impact of an increase in capital requirements reduces credit supply less for single-individual corporations (relative to all other firms). The impact is economically sizeable and statistically significant (in line with the size effect) when included as the only interaction. However, when including an interaction term between size $(\ln ($ total assets) $)$ and required capital in this specification, we no longer find any statistically significant effect for the single-individual NFCs, suggesting that it is the size, rather than the mere fact of being the only individual responsible for the credit, that matters.

\section{$5 \quad$ Extensions and robustness}

In the previous two sections, we have shown that capital requirements affect credit supply and mentioned the channels through which this happens. In this section, we conduct some further analysis on the baseline result, as reported in Table 3. In particular, in subsection 5.1, we conduct a robustness check that should further mitigate concerns about endogeneity of the set required capital levels. Subsequently, we analyze whether banks anticipate the requirement and already alter their credit policy before the announcement (subsection 5.2). In the same subsection, we also investigate non-linearities in the response. We will examine whether the response differs when 
requirements are relaxed versus tightened. Finally, in the last subsection, we explore the robustness of our results in two alternative samples (subsection 5.3).

\subsection{Exogenous capital requirements}

Pillar 2 capital requirements are add-ons to the Pillar 1 requirements that cover for various risks (especially credit risk). As such, they ought to be orthogonal to these risks and could really be considered as exogenous with respect to lending decisions. To further alleviate concerns that changes in bank balance sheet characteristics and various risks are reflected in banks' individual Pillar 2 capital requirements, we follow a test procedure akin to De Marco and Wieladek (2016). In particular, we test whether bank balance sheet variables that supervisors had access to at the time of the regulatory decision can statistically predict the regulatory capital ratio. In a first-stage regression (of which the results are reported in Table A3 of the online appendix), we find little to no role for balance sheet characteristics in explaining the set capital requirements. We include a large set of contemporaneous and/or lagged bank balance sheet characteristics, as well as borrower risk (at a bank's portfolio level), and find that an F-test indicates that they are jointly insignificant (bottom of the table). This indicates that the Pillar 2 capital requirements are exogenous to balance sheet characteristics.

\section{Insert Table 8 around here}

De Marco and Wieladek (2016) label the residuals from such a first stage the "non-balance-sheetbased" capital requirement (as the residual is the capital requirement orthogonalized with respect to balance sheet information). In a second step, we then use these "non-balance-sheet-based" capital requirement to verify if our main findings are altered. More specifically, we substitute in baseline equation (1) the Required capital ratio with the residuals of column 4 of Table A3, which we label Residual required capital ratio. The results are reported in Table 8. Compared to the main results, we find that, if anything, the results become (slightly) stronger, rather than weaker. Compared to Table 3 , the coefficients in Table 8 are slightly larger in absolute value, indicating that the economic impact might even be underestimated without the orthogonalization.

The tests conducted in this subsection thus provide further evidence that we estimate and then quantify the causal impact of capital requirements on various aspects of credit conditions. 


\subsection{Anticipation and asymmetry}

The results from the previous subsection suggest that our main findings can be interpreted in a causal sense as Pillar 2 requirements are exogenously set by the supervisor. Yet, banks may anticipate changes in the requirements and may already start responding immediately, such that we may underestimate the full response. In fact, in Section 2, we explain that the SREP conducted by the NBB consists of several steps. At some point in the process, typically around the beginning of the last quarter of the year, banks may learn about possible future capital requirement decisions. At that stage of the SREP, they may find out through explicit or implicit communication between management teams and supervisors/regulators. Therefore, we conduct a test to examine whether there is a significant pre-announcement effect in the fourth quarter. That is, we investigate whether credit supply in the fourth quarter of year $\mathrm{Y}$ is not only driven by the capital requirement set and communicated at the beginning of year Y, but also by the capital requirement that will be officially announced at the beginning of year $\mathrm{Y}+1$ (but may have already been anticipated by the bank management team).

To that end, we add the following term to the baseline equation (1): $\beta_{5} *$ Required capital ratio ${ }_{b, t+1} *$ $I(Q 4)$ and estimate the wider specification. $I(Q 4)$ is a dummy that equals one in the fourth quarter only. This variable captures the response in the fourth quarter to the capital requirement that will become effective in the next quarter. The results of this additional analysis are reported in the first column of Table 9 . We find that coefficient $\hat{\beta}_{5}$ is negative, statistically significant at the $1 \%$ level and larger (in absolute value) than the point estimate $\hat{\beta}_{1}$ (effect of Required capital ratio). The latter seems to indicate that the leaking of the future capital decision in the fourth quarter and the immediate response to that news is larger than the effect of the required capital ratio actually in place. To shed further light on these differential magnitudes, we run an additional test, where we break down the effect of the Required capital ratio $_{b, t-1}$ into an effect in (i) the first quarter (immediate response to the new requirement), (ii) an effect in quarters two and three (no news, nor leak) and (iii) an effect in the fourth quarter where this could be a response to either the actual requirement announced in the first quarter of the ongoing year or a response to the new requirement which will be in place as of the first quarter of the next year. We obtain a number of interesting findings from the regression results (reported in the second column).

In the first quarter, there is a significant and negative effect of the capital requirement on credit 
supply (point estimate of -0.239). In the two middle quarters of the year, the effect is statistically not distinguishable from zero. Interestingly, in the fourth quarter, credit supply is affected both by the capital decision made in the first quarter of the same year, as well as by the capital decision that will be officially announced in the first quarter of the following year (but may have already been anticipated or leaked). The point estimate of the former $(-0.534)$ is nearly twice as large as the point estimate of the latter $(-0.283)$. Hence, in terms of effective impact on credit supply, the requirement effectively in place in the fourth quarter has a twice as large effect on credit supply as the requirement that will be implemented in the following quarter. In sum, these additional tests show that the actual effect of a change in the capital requirement may be even larger and that the effect of the capital requirement on credit supply predominantly materializes in the first and fourth quarter. This is indicative of both a swift response in the first quarter, combined with substantial end-of-year changes.

\section{Insert Table 9 around here}

In the last column of Table 9, we report the results of a test assessing whether the impact of actual and required capital on credit supply is different when requirements increase strictly, rather than decrease. To that end, we add two additional variables to the baseline specification and estimate:

$$
\begin{array}{rl}
\text { Credit condition (Quarterly) })_{b, f, t}= & \beta_{1} * \text { Required capital } \text { ratio }_{b, t-1} \\
& +\beta_{2} * \text { Previous year required capital } \operatorname{ratio}_{b, t-5} \\
& +\beta_{3} * \text { Actual capital ratio } b, t-1 \\
& +\beta_{4} * \text { Previous year actual capital ratio } \\
b, t-5 \\
& +\beta_{5} * \text { Required capital ratio } \\
b, t-1 & * I\left(\operatorname{Req}_{t-1}>\operatorname{Req}_{t-5}\right) \\
& +\beta_{6} * \text { Actual capital ratio }{ }_{b, t-1} * I\left(\operatorname{Req}_{t-1}>\operatorname{Req}_{t-5}\right) \\
& +\gamma * \text { Bank controls }_{b, t-1}+\nu_{b}+\nu_{f, t}+\epsilon_{b, f, t}
\end{array}
$$

Including these two additional variables changes the interpretation of two other variables. First, coefficient $\beta_{1}\left(\beta_{3}\right)$ now indicates the response of credit supply to the required (actual) capital ratio, when the required capital ratio decreases or remains constant. Second, the sum of the coefficients $\beta_{1}+\beta_{5}$ indicates the response of credit supply to the required capital ratio, when the required capital ratio strictly increases. Third, the sum of coefficients $\beta_{3}+\beta_{6}$ indicates the response of credit supply to the actual capital ratio, when the required capital ratio strictly increases. We find 
that a reduction in the capital requirement increases lending $\left(\hat{\beta}_{1}=-0.59\right)$. An increase in the capital requirement reduces lending $\left(\hat{\beta}_{1}+\hat{\beta}_{5}=-0.59+0.31=-0.28\right)$. However, in absolute value, the impact of a reduction in capital requirements is thus larger than the impact of an equally large increase in the requirements. Moreover, we find that the responsiveness of lending to actual capital changes is larger when banks see an increase in their capital requirement $\left(\hat{\beta}_{3}=0\right.$ and $\left.\hat{\beta}_{6}<0\right)$.

In sum, we do find some preliminary evidence of asymmetric adjustments. In general, the asymmetric response of lending to capital has been investigated using actual capital rather than required capital. A notable exception is Imbierowicz et al. (2018), who study balance sheet responses to both capital requirement increases and decreases using a sample of Danish banks over the period 2007-2014. To the best of our knowledge, there are no papers investigating asymmetric effects of capital requirements on lending using micro data, which makes it difficult to benchmark our results. Nevertheless, the results on required capital are in line with the arguments of De Jonghe and Öztekin (2015). They document that under-capitalized banks actively raise equity (active capital management), whereas over-capitalized banks expand lending and reduce earnings retention (passive capital management). On the one hand, when banks are over-capitalized (or face a reduction in the requirement), they will adjust by expanding their balance sheet (holding equity constant). On the other hand, when they are under-capitalized (and especially when they face an increase in the requirement) they will more likely adjust via active capital management (raising equity) rather than genuine downsizing. We leave a more thorough analysis of asymmetric responses (and other non-linearities) for future research, ideally using a longer timespan and wider range of banks (e.g., all banks supervised in the Single Supervisory Mechanism).

\subsection{Opposite capital changes and single-bank borrowers}

While we restrict the sample to multiple bank borrowers to better isolate supply from demand effects, it could still be that borrowers match with specific banks. If firms borrow from multiple banks, but are similar in terms of (required) capital ratio, it may be hard to identify statistical relationships. Therefore, we redo the analysis using a slightly different sample. More specifically, we only keep firms in the sample if they borrow, in one and the same quarter, from at least one bank that experiences a negative change in the required capital ratio, and at least one bank that experiences a strictly positive change in the required capital ratio. In panel A of Table A4 in the 
online appendix, we report these results. The specification is similar to the baseline equation (1) but we thus impose an additional constraint on the multiple borrower sample. This additional criterium implies that the sample size shrinks to about $70 \%$ of the sample used in Table 3. Nevertheless, the results in both tables are very similar, except for the utilization rate regression. An increase in required and/or actual capital ratios reduces credit supply. Moreover, capital requirements have a long-lasting effect.

In panel B of Table A4, we report results for a substantially larger sample, which has nearly three times as many observations as the baseline results. The difference stems from the inclusion of single-bank borrowers. All regression specifications reported in Table 3 include firm $\mathrm{x}$ time fixed effects, and are hence comparing credit supply to the same firm in the same quarter, by two banks with different regulatory capital. However, this implies that one can only include firm-quarter observations if that firm borrows simultaneously from at least two banks. The multiple-bank borrower sample consists of 1,022,324 bank-firm-quarter observations involving 64,183 firms. Firms borrowing from more than one bank typically borrow from two banks, with a maximum of six banks. However, in the Belgian context, the majority of firms borrow from a single banks. The full sample, including single-bank borrowers, has 3,338,729 bank-firm-quarter observations covering 316,969 unique firms. Hence, only about a fifth of the firms borrow from two or more banks in a given quarter, which explains why the average (median) firm in our sample has 1.373 (1) bank relationships. While focusing on multiple-bank borrowers may have methodological merit, as it makes it possible to control for demand like Khwaja and Mian (2008), it also implies a substantial reduction in the sample size, especially dropping smaller firms, potentially leading to misguided conclusions for the entire universe of firms; i.e., single-bank and multiple-bank borrowers (see Degryse et al. (2019)).

Therefore, we also redo the analysis using the full sample. In order to mitigate concerns about confounding credit demand effects, we now include a 'group' fixed effect to control for credit demand. The group is defined as the firm itself, in the case of a firm with multiple bank relationships in a given quarter. The single-bank firms are, in each quarter, grouped on the basis of sector affiliation, firm location, and size (hereafter referred to as ILS or industry-location-size). More specifically, these firms are grouped according to the deciles of loan size in the Credit Register, the two-digit NACE code and the two-digit postal code (which broadly coincides with the district level). A similar approach is used by Edgerton (2012), Morais et al. (2018), Degryse et al. (2019) and 
De Jonghe et al. (2019). The results for the full sample estimation are reported in panel B of Table A4. In cases where the point estimate is significantly different from zero, we find that the established relationships are quantitatively similar. That is, point estimates are by and large the same in the full sample and the multiple-bank borrower sample. However, we do observe that some of the previously found relationships are no longer statistically significant. This could be due to two reasons. On the one hand, it could be caused by only imperfectly controlling for firm demand, if firms in an industry-location-sector group have differential demand shocks in a given quarter. On the other hand, even if firms in such bins are homogeneous, the results could still differ if the characteristics of the firms that borrow from a single bank are different from those of the multiple-bank firms. Two dimensions in which they may differ are firm size and firm age. Degryse et al. (2019) show (in their Table 1) that single-bank firms are, on average, significantly smaller and younger than multiple-bank firms. As we have shown that the impact of required capital on credit supply is firm size-dependent, it may also explain the different effects in the multiple borrower sample versus the full sample.

\section{Regulatory capital and balance sheet effects}

Using detailed bank-firm level data on credit and applying micro-econometric techniques has many advantages, especially with regard to identification and causality, but also with respect to contributions to the literature. One drawback, however, is that the analysis is then focused on one lending market only, namely corporate lending, and also ignores other balance sheet changes banks make in response to higher capital requirements. In this section, we empirically test how regulatory capital may affect the composition of the balance sheet. Balance sheet and income statement data come from (confidential) filings with the National Bank of Belgium (i.e., Format A).

The empirical specification used to document the relationship between (required) regulatory capital and bank balance sheet effects mimics that of Equation (1), with the crucial difference that the level of observation is at the bank-quarter level: 


$$
\begin{aligned}
\text { Growth (Quarterly) of } \mathrm{X}_{b, t}= & \beta_{1} * \text { (Residual) Required capital ratio }{ }_{b, t-1} \\
& +\beta_{2} * \text { Previous year required capital ratio }_{b, t-5} \\
& +\beta_{3} * \text { Actual rapital ratio }{ }_{b, t-1} \\
& +\beta_{4} * \text { Previous year actual capital ratio } \text { rat }_{b, t} \\
& +\gamma * \text { Bank controls }_{b, t-1}+\nu_{b}+\nu_{t}+\epsilon_{b, t}
\end{aligned}
$$

The dependent variable, Growth (quarterly) of $\mathrm{X}_{b, t}$, is the quarterly percentage change in a specific aggregate balance sheet item. We relate quarterly growth rates in nine broad asset categories and six broad funding categories to lagged actual and required regulatory capital ratios. ${ }^{12}$ The asset classes we consider are: cash interbank assets, mortgages, term loans (domestic), term loans (foreign), other loans, securities, other assets, total assets (domestic) and total assets. Regarding banks' funding sources, we look at quarterly growth in interbank liabilities, retail deposits, wholesale deposits, other debt, total liabilities and common equity. Summary statistics on these variables are reported in Table 10. In panel A, we provide information on the growth rates, and on their share in total assets in panel B. The four independent variables of interest are based on the regulatory capital data (and are defined as before).

\section{Insert Table 10 around here}

The vector Bank Controls ${ }_{b, t-1}$ consists of the following variables: bank size (natural logarithm of total assets), loans to total assets ratio, loans to deposits ratio, off-balance sheet to total assets ratio, share of demand and savings deposits in total deposits, quarterly return on equity, provisions to total loans, and the share of interest income in total income, which are all lagged by one quarter to mitigate reverse causality concerns. $\nu_{b}$ is a bank fixed effect and $\nu_{t}$ is a time fixed effect. Among other things, the former is a crude proxy for time-invariant heterogeneity in banks' borrower pools, which may create heterogeneous demand for that asset type; whereas the latter accounts for general macro-economic factors.

\footnotetext{
${ }^{12}$ As with the micro data, prior to running the main regression, we run auxiliary regressions to analyze the scope for collinearity due to correlation between the actual and required capital ratio and/or correlation between the current and lagged values. Variance inflation factors (VIFs) are low and range between 1.15 for the required capital ratio, and 1.47 for the previous year required capital ratio. These VIFs are sufficiently low not to have to worry about possible consequences of collinearity.
} 
Importantly, rather than estimating Equation (5) separately for each of the fifteen growth rates, we estimate them as a system of equations (that has a similar right-hand-side structure for each equation). In particular, using a seemingly unrelated equation estimator makes it possible to take into account cross-equation (residual) correlation. Seemingly related regression estimation also allows for more flexibility in the modeling of the variance/covariance matrix, such as clustering standard errors at bank level.

We report the estimation results in Table 11, in which each row corresponds to one regression in the system. The first column mentions the dependent variable, whereas the other columns provide information on the coefficients of interest, the number of observations and the R-squared. In the last column, we also report the $\mathrm{p}$-value of a test of the hypothesis that $\beta_{1}+\beta_{3}=0$. We thus again also test whether the impact of changes in regulatory capital requirements, when banks hold their buffer constant, is significantly different from zero. The results on assets are reported in panel A of Table 11, while those on liabilities are in panel B.

\section{Insert Table 11 around here}

When inspecting the results in panel A and focusing exclusively on the impact of the required capital ratio, we find that all but one asset categories are reduced when capital requirements are higher, and significantly so for seven out of nine dependent variables. The coefficients also allow for an easy comparison of the magnitude of the effects across asset classes. The three largest asset classes (mortgages, domestic term loans, securities) represent $70 \%$ of the average bank's balance sheet (see panel B of Table 10). The effects on the first two are relatively similar in magnitude and is slightly larger (in absolute value) for securities growth. The effects are much more sizeable for foreign term loans and other loans, but these are much smaller asset categories. Consequently, the impact on (domestic) total assets is in line with the estimated effects on the three most important asset categories.

Turning to bank funding, we find that an increase in capital requirements is associated with a reduction in both retail and wholesale deposits. The effect on wholesale deposits is economically very large, but, for the average bank, this type of funding is relatively unimportant $(6.7 \%)$ vis-

à-vis retail funding (66.7\%). Higher capital requirements also lead to larger equity growth (but not significantly so). Unfortunately, detailed information on dividend policies, earnings retention 
or active equity issuance are not available, which limits the scope to analyze what drives equity growth and thus show which mechanisms banks use to build up their capital levels. In sum, we find sizeable deleveraging in response to higher capital requirements. ${ }^{13}$

As regards the other independent variables, whenever significant, they have a similar sign to the required capital ratio. The results discussed above pertain to a model where we use the residual required capital ratio (see subsection 5.1). Results using the required capital ratio are reported in the online appendix A5. Like the case of the microdata, the coefficients are slightly larger (in absolute value) when using the residuals (i.e., the "non-balance-sheet-based" capital requirement).

To conclude this section, the aggregate balance sheet data analysis shows effects of (required) capital changes on bank activities. While the results are intuitive and interesting, the set-up is not necessarily perfect. First, we examine broad asset class and hence ignore the scope for heterogeneity within such an asset class for a given bank (a bank can substitute risky securities for safe securities) or between banks (clientèle effects). Moreover, an analysis with aggregate data may suffer from other biases, such as imperfectly controlling for unobserved firm demand or borrower quality, leading to biased estimates. The results in the last section thus mainly serve the purpose of showing what happens in credit markets (other than those that serve NFCs), for which we unfortunately do not have such granular data. An interesting avenue for further research would explore, within a given country and with micro data from a household credit register, a corporate credit register and a securities register, how banks strategically behave in different markets in response to higher capital requirements.

\section{Conclusion}

In general, macro-prudential policy has the explicit goal to safeguard the resilience of the financial system. One instrument at its disposal to mitigate the impact of credit or financial cycles is the

\footnotetext{
${ }^{13}$ Various editions of the Financial Stability Report issued by the National Bank of Belgium describe that there were no complementary measures or deleveraging pressures/incentives during our sample period. Most, if not all, of the forced deleveraging following the global financial crisis of 2007-08 was finalized before the start of our sample period. The initial deleveraging (during 2008-2009) was mainly because of agreements with the European Commission regarding state aid received by some of the major Belgian players. Compared to their European peers, Belgian banks started the deleveraging process earlier and more extensively. The remaining minor deleveraging in 2012 and 2013 is mainly observed in the derivatives portfolio (off-balance sheet), and thus does not affect our results.
} 
countercyclical capital buffer. The build-up of capital buffers during booms provides financial room in downturns that helps mitigate credit crunches. Moreover, in some cases, higher capital requirements can also help to slow down credit booms, if banks internalize more of the potential social costs of defaults. Micro-prudential capital requirements do not have the objective of affecting credit supply, but rather aim at enhancing the soundness and stability of individual financial institutions. Nevertheless, micro-prudential capital requirements may also affect bank activity and lending, if raising capital internally or externally is costly. Whether this is the case is a widely debated issue, as it would imply that there are costs or frictions associated with bank capital that lead banks to pass up on otherwise profitable loans.

Using two alternative approaches, we document that higher capital requirements correspond to lower credit supply to corporations as well as balance sheet adjustments. We also show that the effects are, first, less pronounced for banks for which the cost of capital (internally or externally) is lower and, second, more prevalent for firms that facilitate swifter adjustments to banks' riskweighted assets ratio. Moreover, the heterogeneous treatment of borrowers by banks that face higher capital requirements are rational and may even be welfare-improving by reducing credit less to safer firms as well as younger firms. Finally, we also find that the impact on aggregate corporate lending is, in economic terms, moderate, suggesting that the impact on real activity might be limited.

Overall, the unintended consequences of micro-prudential capital requirements on credit supply are present but may be small, under the right conditions. For example, the required adjustments to bank capital were small and gradual, making it possible for banks to meet them fairly smoothly. In addition, banks were dealt with individually, and additional requirements did not necessarily correlate in time, so that the capacity existed both internally in the bank and externally in the markets and among firms to absorb the increases in individual bank capital requirements. The fact that, despite this benign environment, our paper still provides new well-identified evidence of an economically relevant impact of changes in bank capital requirements on bank lending to corporations and other bank balance sheet items, should come as a poignant reminder to academics and policymakers alike not to overlook the possible market frictions that banks face when raising new capital.

Finally, an interesting avenue for research is exploring the impact of these Pillar 2 requirements on 
credit supply in a multi-country set-up. Since the introduction of the Single Supervisory Mechanism in 2014, the European Central Bank is in charge of the micro-prudential supervision of significant financial institutions of the euro area. It could be interesting to explore whether country-specific features are an additional source of heterogeneity (alongside bank and firm characteristics) in the impact of capital requirements on credit supply. 


\section{References}

Admati, A. R., DeMarzo, P. M., Hellwig, M. F., Pfleiderer, P. C., 2013. Fallacies, irrelevant facts, and myths in the discussion of capital regulation: Why bank equity is not socially expensive. Stanford GSB Working Paper No. 2065.

Admati, A. R., Hellwig, M. F., 2013. The bankers' new clothes: what's wrong with banking and what to do about it. Princeton University Press, Princeton NJ.

Adrian, T., Boyarchenko, N., 2012. Intermediary leverage cycles and financial stability. Federal Reserve Bank of New York, Staff Reports 567.

Adrian, T., Shin, H. S., 2010. Liquidity and leverage. Journal of Financial Intermediation 19 (3), $418-437$.

Aiyar, S., Calomiris, C., Hooley, J., Korniyenko, Y., Wieladek, T., 2014a. The international transmission of bank capital requirements: Evidence from the UK. Journal of Financial Economics $113(3), 368-382$.

Aiyar, S., Calomiris, C., Wieladek, T., 2014b. Does macro-prudential regulation leak? Evidence from a UK policy experiment. Journal of Money, Credit and Banking 46 (s1), 181-214.

Aiyar, S., Calomiris, C. W., Wieladek, T., 2016. How does credit supply respond to monetary policy and bank minimum capital requirements? European Economic Review 82, 142 - 165.

Angelini, P., Neri, S., Panetta, F., 2014. The interaction between capital requirements and monetary policy. Journal of Money, Credit and Banking 46 (6), 1073-1112.

Angeloni, I., Faia, E., 2013. Capital regulation and monetary policy with fragile banks. Journal of Monetary Economics 60 (3), 311 - 324 .

Ashcraft, A. B., 2006. New evidence on the lending channel. Journal of Money, Credit and Banking $38(3), 751-775$.

Auer, R., Ongena, S., 2016. The countercyclical capital buffer and the composition of bank lending. Mimeo.

Bahaj, S., Bridges, J., Malherbe, F., O’Neill, C., 2016. What determines how banks respond to changes in capital requirements? Bank of England Working Paper No. 593. 
Baker, M., Wurgler, J., 2015. Do strict capital requirements raise the cost of capital? Bank regulation, capital structure, and the low-risk anomaly. American Economic Review 105 (5 (May)), $315-20$.

Berger, A., Bouwman, C. H., 2013. How does capital affect bank performance during financial crises? Journal of Financial Economics 109 (1), 146 - 176.

Berger, A., Udell, G. F., 1994. Did risk-based capital allocate bank credit and cause a "credit crunch" in the United States? Journal of Money, Credit and Banking 26, 585-628.

Bernanke, B., Lown, C., 1991. The credit crunch. Brookings Papers on Economic Activity 22 (2), 205-239.

Berrospide, J., Edge, R., 2010. The effects of bank capital on lending: What do we know, and what does it mean? International Journal of Central Banking 6 (4), 5-54.

Bridges, J., Gregory, D., Nielsen, M., Pezzini, S., Radia, A., Spaltro, M., 2014. The impact of capital requirements on bank lending. Bank of England working papers 486.

Célérier, C., Kick, T., Ongena, S., 2016. Changes in the cost of bank equity and the supply of bank credit: when it rains in milano or brussels, does it drizzle in frankfurt? Mimeo.

Cernov, M., Urbano, T., 2018. Identification of EU bank business models. EBA Staff paper series $(2)$.

De Jonghe, O., Dewachter, H., Mulier, K., Ongena, S., Schepens, G., 2019. Some borrowers are more equal than others: Bank funding shocks and credit reallocation. Review of Finance, forthcoming.

De Jonghe, O., Öztekin, Ö., 2015. Bank capital management: International evidence. Journal of Financial Intermediation 24 (2), $154-177$.

De Marco, F., Wieladek, T., 2016. The real effects of capital requirements and monetary policy: Evidence from the United Kingdom. CEPR Discussion Paper No. DP11265.

Degryse, H., De Jonghe, O., Jakovljevic, S., Mulier, K., Schepens, G., 2019. Identifying credit supply shocks with bank-firm data: Methods and applications. Journal of Financial Intermediation, forthcoming. 
Du, C., Miles, D., 2014. Interaction between monetary policy and regulatory capital requirements. Centre for Economic Policy Research DP10200.

Edgerton, J., 2012. Credit supply and business investment during the great recession: Evidence from public records of equipment financing. Working Paper.

Fahlenbrach, R., Prilmeier, R., Stulz, R. M., 2012. This time is the same: Using bank performance in 1998 to explain bank performance during the recent financial crisis. The Journal of Finance $67(6), 2139-2185$.

Fraisse, H., Lè, M., Thesmar, D., 2019. The real effects of bank capital requirements. Management Science, forthcoming.

Freixas, X., Rochet, 2008. Microeconomics of banking. MIT Press, Cambridge MA.

Galati, G., Moessner, R., 2013. Macroprudential policy: A literature review. Journal of Economic Surveys $27(5), 846-878$.

Gandhi, P., Lustig, H., 2015. Size anomalies in U.S. bank stock returns. The Journal of Finance $70(2), 733-768$.

Gornall, W., Strebulaev, I., 2018. Financing as a supply chain: The capital structure of banks and borrowers. Journal of Financial Economics 129 (3), 510-530.

Gropp, R., Mosk, T., Ongena, S., Wix, C., 04 2018. Banks Response to Higher Capital Requirements: Evidence from a Quasi-Natural Experiment. The Review of Financial Studies 32 (1), 266-299.

Hanson, S. G., Kashyap, A. K., Stein, J. C., 2011. A macroprudential approach to financial regulation. Journal of Economic Perspectives 25 (1), 3-28.

Hubbard, G., Kuttner, K. N., Palia, D., 2002. Are there bank effects in borrowers' costs of funds? Evidence from a matched sample of borrowers and banks. The Journal of Business 75 (4), 559-81.

Imbierowicz, B., Kragh, J., Rangvid, J., 2018. Time-varying capital requirements and disclosure rules: Effects on capitalization and lending decisions. Journal of Money, Credit and Banking $50(4), 573-602$. 
Jeanne, O., Korinek, A., 2013. Macroprudential regulation versus mopping up after the crash. National Bureau of Economic Research, WP 18675.

Jiménez, G., Ongena, S., Peydró, J.-L., Saurina, J., 2017. Macroprudential policy, countercyclical bank capital buffers, and credit supply: Evidence from the spanish dynamic provisioning experiments. Journal of Political Economy 125 (6), 2126-2177.

Juelsrud, R., Wold, E. G., 2019. Risk-weighted capital requirements and portfolio rebalancing. Journal of Financial Intermediation, forthcoming.

Kashyap, A., Stein, J. C., Hanson, S. G., 2010. An analysis of the impact of 'substantially heightened' capital requirements on large financial institutions. Mimeo.

Khwaja, A., Mian, A., 2008. Tracing the impact of bank liquidity shocks: Evidence from an emerging market. American Economic Review 98:4, 1413-1442.

Labonne, C., Lamé, G., 2018. Credit growth and bank capital requirements identification using supervisory ratings. Unpublished manuscript.

Malherbe, F., 2015. Optimal capital requirements over the business and financial cycles. European Central Bank, WP1830.

Mésonnier, J.-S., Monks, A., 2015. Did the EBA capital exercise cause a credit crunch in the euro area? International Journal of Central Banking 11 (3), 75-117.

Mora, N., Logan, A., 2012. Shocks to bank capital: evidence from UK banks at home and away. Applied Economics 44 (9), 1103-1119.

Morais, B., Peydro, J. L., Ruiz Ortega, C., 2018. The international bank lending channel of monetary policy rates and QE: Credit supply, reach-for-yield, and real effects. Journal of Finan, forthcoming.

Morrison, A. D., White, L., 2005. Crises and capital requirements in banking. American Economic Review 95 (5), 1548-572.

Peek, J., Rosengren, E., 2000. Collateral damage: Effects of the Japanese bank crisis on real activity in the United States. American Economic Review 90, 30-45. 
Puri, M., Rocholl, J., Steffen, S., 2011. Global retail lending in the aftermath of the US financial crisis: Distinguishing between supply and demand effects. Journal of Financial Economics 100, $556-578$.

Shleifer, A., Vishny, R. W., 2010. Unstable banking. Journal of Financial Economics 97 (3), 306 318.

Tirole, J., 2006. The theory of corporate finance. Princeton University Press. 
Figure 1: Diagram of the Supervisory Review and Evaluation Process

The flow chart depicts the various steps and ingredients in the Supervisory Review and Evaluation Process (SREP). On the left-hand side, the various inputs to SREP are listed. NBB is shorthand for National Bank of Belgium and ICAAP stands for internal capital adequacy assessment process. The inputs are used to perform an analysis and risk assessment, which are quantified by means of a scorecarding system. The output of the SREP are prudential measures which could consist of three components: an action plan, a specific capital decision or other measures. The International Monetary Fund writes in detail, in its 2013 Financial Sector Assessment Plan, on compliance of the SREP with the Basel Core Principles for effective banking supervision. In particular, it mentions that "the NBB's approach to Pillar 2 is well developed using a scorecard as the primary tool for risk analysis, taking into account qualitative and quantitative measures. At least on an annual basis, the NBB determines the minimum capital adequacy requirements for all banks on a forward looking basis. The SREP and Internal Capital Adequacy Assessment Procedure analysis are important inputs into the process as are, if available, outputs from banks' economic capital models. Stress testing is also taken into account as to ascertain whether the bank is able to maintain capital buffers under stress conditions." (see IMF Country Report No. $13 / 133)$.

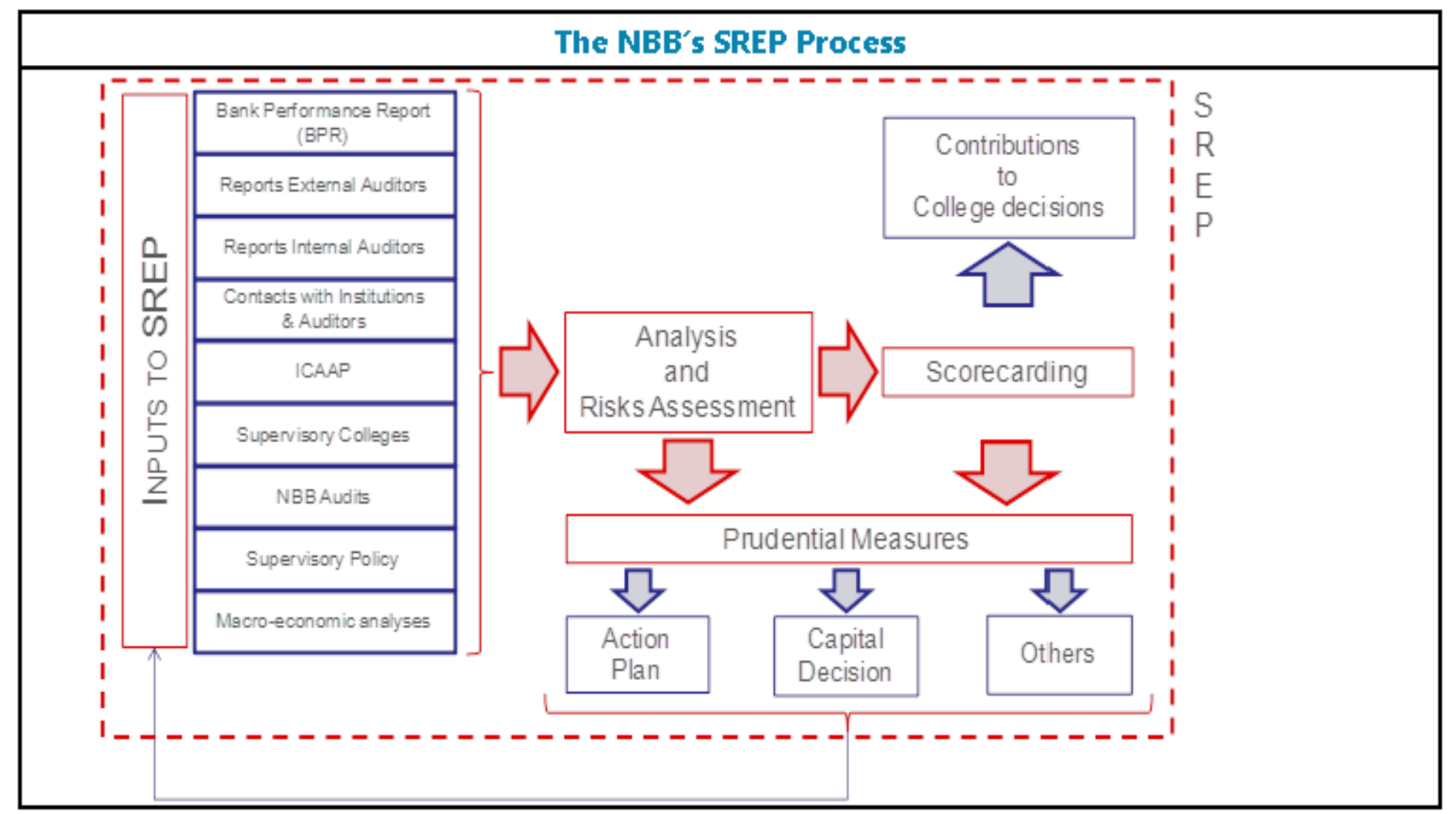

Source: Prudential regulation and supervision, NBB Report 2015, p. 239. 
Table 1: Summary statistics: Bank-level data

This table contains summary statistics on (regulatory) bank capital (panel A) and bank-specific characteristics (panel B). Data come either from the SREP (bank capital) or the regulatory filings (balance sheet and income statement) and are on the bank-quarter level. Stock data are measured at the end of the quarter. Flow data are changes accumulated over the quarter. The total number of observations is 132, but is unbalanced over 12 quarters (2013Q1 to 2015Q4) and concerns 14 banks. Variables are winsorized at the $2 \%$ level.

\begin{tabular}{|c|c|c|c|c|c|}
\hline & mean & $\begin{array}{l}\text { standard } \\
\text { deviation }\end{array}$ & $\begin{array}{c}5 \text { th } \\
\text { percentile }\end{array}$ & median & $\begin{array}{c}\text { 95th } \\
\text { percentile }\end{array}$ \\
\hline \multicolumn{6}{|l|}{ Panel A: Actual and required capital ratio } \\
\hline $\begin{array}{l}\text { Required capital ratio } \\
\text { Previous year required capital ratio } \\
\text { Actual capital ratio } \\
\text { Previous year actual capital ratio }\end{array}$ & $\begin{array}{l}0.110 \\
0.110 \\
0.149 \\
0.151\end{array}$ & $\begin{array}{l}0.019 \\
0.024 \\
0.038 \\
0.043\end{array}$ & \multicolumn{3}{|c|}{$\begin{array}{l}\text { not reported due to } \\
\text { data confidentiality reasons }\end{array}$} \\
\hline \multicolumn{6}{|l|}{ Panel B: Bank characteristics } \\
\hline $\begin{array}{l}\ln \text { (Total assets) } \\
\text { Loans to total assets } \\
\text { Loans to deposits } \\
\text { Off-balance-sheet items to total assets } \\
\text { Share of demand and savings deposits } \\
\text { (quarterly) Return on equity } \\
\text { (quarterly) Provisions to loans } \\
\text { (quarterly) Interest income share }\end{array}$ & $\begin{array}{l}9.867 \\
0.534 \\
0.945 \\
6.370 \\
0.800 \\
0.102 \\
0.001 \\
0.610\end{array}$ & $\begin{array}{l}1.672 \\
0.174 \\
0.639 \\
5.494 \\
0.109 \\
0.127 \\
0.001 \\
0.278\end{array}$ & $\begin{array}{c}7.077 \\
0.035 \\
0.553 \\
1.438 \\
0.594 \\
-0.075 \\
-0.000 \\
0.142\end{array}$ & $\begin{array}{l}9.835 \\
0.544 \\
0.784 \\
3.144 \\
0.817 \\
0.102 \\
0.000 \\
0.712\end{array}$ & $\begin{array}{c}12.247 \\
0.766 \\
2.556 \\
16.127 \\
0.946 \\
0.285 \\
0.003 \\
0.893\end{array}$ \\
\hline
\end{tabular}


Table 2: Summary statistics: Firm-bank level data

This table contains summary statistics on corporate credit (panel A) and bank characteristics (panel B). The unit of observation is a (firm, bank, quarter) triplet. In panel A, we provide information on various aspects of corporate credit such as the authorized amount, the number of relationships, credit provision at the intensive margin (credit growth and large drop in credit) as well as the extensive margin (new bank-firm relationship), utilization rates of granted credit, term credit growth as well as the degree of collateralization. In panel B, we report summary statistics on the independent variables included in subsequent regressions. Observations at the bankfirm-quarter level are winsorized at the $1 \%$ level.

\begin{tabular}{|c|c|c|c|c|c|c|}
\hline Variable & Observations & Mean & Std.Dev & $\begin{array}{c}5 \text { th } \\
\text { percentile }\end{array}$ & median & $\begin{array}{c}95 \mathrm{th} \\
\text { percentile }\end{array}$ \\
\hline \multicolumn{7}{|l|}{ Panel A: Credit growth } \\
\hline $\begin{array}{l}\text { Authorized credit amount } \\
\text { Number of relationships } \\
\text { Credit growth } \\
\text { Large drop in credit } \\
\text { New bank-firm relationship } \\
\text { Utilization rate } \\
\text { Term credit growth } \\
\text { Collateralization rate }\end{array}$ & $\begin{array}{c}1,022,297 \\
1,022,297 \\
1,022,297 \\
1,022,297 \\
1,067,376 \\
1,067,376 \\
577,073 \\
1,022,297\end{array}$ & $\begin{array}{c}644,563 \\
2.219 \\
-0.029 \\
0.233 \\
0.022 \\
0.667 \\
-0.067 \\
0.616\end{array}$ & $\begin{array}{l}7,749,937 \\
0.468 \\
0.237 \\
0.423 \\
0.148 \\
0.391 \\
0.320 \\
0.637\end{array}$ & $\begin{array}{c}2,500 \\
2.000 \\
-0.325 \\
0.000 \\
0.000 \\
0.000 \\
-0.549 \\
0.000\end{array}$ & $\begin{array}{c}75,723 \\
2.000 \\
-0.012 \\
0.000 \\
0.000 \\
0.877 \\
-0.045 \\
0.463\end{array}$ & $\begin{array}{c}1,569,095 \\
3.000 \\
0.182 \\
1.000 \\
0.000 \\
1.000 \\
0.314 \\
2.000\end{array}$ \\
\hline \multicolumn{7}{|c|}{ Panel B: Bank characteristics (estimation sample, SREP banks) } \\
\hline $\begin{array}{l}\text { Required capital ratio } \\
\text { Previous year required capital ratio } \\
\text { Actual capital ratio } \\
\text { Previous year actual capital ratio } \\
\text { (lagged) Log total assets } \\
\text { (lagged) Quarterly growth of common equity } \\
\text { (lagged) Quarterly growth of deposits } \\
\text { (lagged) Quarterly growth of total assets } \\
\text { (lagged) Return on equity } \\
\text { Default probability }\end{array}$ & $\begin{array}{l}1,022,297 \\
1,022,297 \\
1,022,297 \\
1,022,297 \\
1,022,297 \\
1,022,297 \\
1,022,297 \\
1,022,297 \\
1,022,297 \\
1,022,297\end{array}$ & $\begin{array}{c}0.109 \\
0.107 \\
0.155 \\
0.161 \\
11.643 \\
0.005 \\
0.011 \\
-0.007 \\
0.095 \\
0.045\end{array}$ & $\begin{array}{l}0.015 \\
0.015 \\
0.029 \\
0.033 \\
0.883 \\
0.060 \\
0.063 \\
0.062 \\
0.093 \\
0.142\end{array}$ & $\begin{array}{c}9.293 \\
-0.108 \\
-0.030 \\
-0.083 \\
-0.082 \\
0.001\end{array}$ & $\begin{array}{c}11.958 \\
0.020 \\
0.005 \\
0.002 \\
0.092 \\
0.009\end{array}$ & $\begin{array}{c}12.268 \\
0.095 \\
0.052 \\
0.081 \\
0.233 \\
0.170\end{array}$ \\
\hline
\end{tabular}


Table 3: Capital (requirements) and credit supply: baseline results

This table contains estimation results from a regression relating various dimensions of credit growth to (regulatory) capital ratios. More specifically, we run the following regression for six different dependent variables:

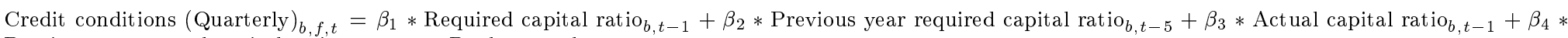
Previous year actual capital ratio ${ }_{b, t-5}+\gamma *$ Bank controls $_{b, t-1}+\nu_{b}+\nu_{f, t}+\epsilon_{b, f, t}$

Besides the variables of interest (the labels of which are reported in bold), the model includes lagged control variables, which are: the natural logarithm of total assets, quarterly growth in common equity, quarterly growth in deposits, quarterly growth in total assets and quarterly return on equity. In all regressions, we also control for a bank-specific assessment of the firm's default probability. These variables have been lagged one quarter such that they are in predetermined with respect to next quarter's credit growth at the bank-firm level. In addition, we also include a bank fixed effect $\left(\nu_{b}\right)$. $\nu_{f, t}$ is a firm $\mathrm{x}$ time fixed effect that captures time-varying firm demand shifters. Standard errors are clustered at bank level. At the bottom of the table, we also provide information on the p-values of various tests on the coefficients of interest.

\begin{tabular}{|c|c|c|c|c|c|c|}
\hline VARIABLES & $\begin{array}{c}(1) \\
\text { Credit } \\
\text { growth }\end{array}$ & $\begin{array}{l}\text { Large drop in } \\
\text { credit }\end{array}$ & $\begin{array}{c}(3) \\
\text { New } \\
\text { bank-firm } \\
\text { relationships }\end{array}$ & $\begin{array}{l}(4) \\
\begin{array}{l}\text { Utilization } \\
\text { rate }\end{array}\end{array}$ & $\begin{array}{c}(5) \\
\text { Credit } \\
\text { growth - } \\
\text { Term loans }\end{array}$ & $\begin{array}{c}(6) \\
\begin{array}{c}\text { Collateral } \\
\text { rate }\end{array}\end{array}$ \\
\hline Required capital ratio & $\begin{array}{c}-0.129^{*} \\
(0.067)\end{array}$ & $\begin{array}{c}0.333 \\
(0.264)\end{array}$ & $\begin{array}{c}-0.808^{* * *} \\
(0.245)\end{array}$ & $\begin{array}{l}0.285^{*} \\
(0.152)\end{array}$ & $\begin{array}{c}-0.310^{* *} \\
(0.135)\end{array}$ & $\begin{array}{c}0.526 \\
(0.440)\end{array}$ \\
\hline Previous year required capital ratio & $\begin{array}{c}-0.251^{* * *} \\
(0.050)\end{array}$ & $\begin{array}{c}0.395^{*} \\
(0.184)\end{array}$ & $\begin{array}{c}-0.858^{* * * *} \\
(0.198)\end{array}$ & $\begin{array}{c}0.090 \\
(0.126)\end{array}$ & $\begin{array}{c}-0.283^{* *} \\
(0.101)\end{array}$ & $\begin{array}{l}-0.828 \\
(0.625)\end{array}$ \\
\hline Actual capital ratio & $\begin{array}{c}-0.136^{* *} \\
(0.053)\end{array}$ & $\begin{array}{c}0.434 * * \\
(0.167)\end{array}$ & $\begin{array}{c}0.065 \\
(0.095)\end{array}$ & $\begin{array}{c}0.200 * * \\
(0.072)\end{array}$ & $\begin{array}{c}-0.258^{* *} \\
(0.115)\end{array}$ & $\begin{array}{l}-0.807^{*} \\
(0.426)\end{array}$ \\
\hline Previous year actual capital ratio & $\begin{array}{l}-0.009 \\
(0.048)\end{array}$ & $\begin{array}{c}-0.034 \\
(0.074)\end{array}$ & $\begin{array}{l}-0.079 \\
(0.100)\end{array}$ & $\begin{array}{c}0.019 \\
(0.077)\end{array}$ & $\begin{array}{c}0.048 \\
(0.127)\end{array}$ & $\begin{array}{c}0.101 \\
(0.223)\end{array}$ \\
\hline (lagged) Log total assets & $\begin{array}{c}0.014 \\
(0.016)\end{array}$ & $\begin{array}{c}-0.038^{*} \\
(0.018)\end{array}$ & $\begin{array}{c}-0.363^{* * *} \\
(0.085)\end{array}$ & $\begin{array}{l}-0.002 \\
(0.011)\end{array}$ & $\begin{array}{c}0.011 \\
(0.022)\end{array}$ & $\begin{array}{c}0.123^{* * *} \\
(0.037)\end{array}$ \\
\hline (lagged) Quarterly growth in common equity & $\begin{array}{c}-0.043^{* *} \\
(0.015)\end{array}$ & $\begin{array}{l}0.047^{*} \\
(0.025)\end{array}$ & $\begin{array}{c}0.005 \\
(0.013)\end{array}$ & $\begin{array}{c}0.049 * * * \\
(0.008)\end{array}$ & $\begin{array}{c}-0.095 * * * \\
(0.028)\end{array}$ & $\begin{array}{l}-0.015 \\
(0.034)\end{array}$ \\
\hline (lagged) Quarterly growth in deposits & $\begin{array}{c}0.009 \\
(0.006)\end{array}$ & $\begin{array}{c}0.015 \\
(0.0110)\end{array}$ & $\begin{array}{c}-0.057^{* *} \\
(0.023)\end{array}$ & $\begin{array}{l}-0.013 \\
(0.015)\end{array}$ & $\begin{array}{l}-0.012 \\
(0.016)\end{array}$ & $\begin{array}{c}-0.069 * \\
(0.034)\end{array}$ \\
\hline (lagged) Quarterly growth in total assets & $\begin{array}{l}-0.019 \\
(0.012)\end{array}$ & $\begin{array}{c}0.054^{* * *} \\
(0.016)\end{array}$ & $\begin{array}{c}0.101 * * * \\
(0.028)\end{array}$ & $\begin{array}{c}0.079^{* * *} \\
(0.017)\end{array}$ & $\begin{array}{l}0.043^{*} \\
(0.024)\end{array}$ & $\begin{array}{c}-0.089^{* * *} * \\
(0.019)\end{array}$ \\
\hline (lagged) Quarterly return on equity & $\begin{array}{c}0.025 \\
(0.018)\end{array}$ & $\begin{array}{l}-0.038 \\
(0.033)\end{array}$ & $\begin{array}{l}-0.038 \\
(0.033)\end{array}$ & $\begin{array}{l}-0.009 \\
(0.009)\end{array}$ & $\begin{array}{c}0.026 \\
(0.023)\end{array}$ & $\begin{array}{l}-0.006 \\
(0.028)\end{array}$ \\
\hline Default probability & $\begin{array}{c}-0.040 * * * \\
(0.006)\end{array}$ & $\begin{array}{l}0.032^{*} \\
(0.016)\end{array}$ & $\begin{array}{c}-0.015^{* * *} \\
(0.004)\end{array}$ & $\begin{array}{c}0.117^{* * *} \\
(0.016)\end{array}$ & $\begin{array}{c}-0.034 * * * \\
(0.009)\end{array}$ & $\begin{array}{c}0.291^{* * *} \\
(0.051)\end{array}$ \\
\hline Observations & $1,022,297$ & $1,022,297$ & $1,067,376$ & $1,067,376$ & 577,073 & $1,022,297$ \\
\hline R-squared & 0.47 & 0.50 & 0.51 & 0.58 & 0.48 & 0.54 \\
\hline Firm*time fixed effects & Yes & Yes & Yes & Yes & Yes & Yes \\
\hline Bank fixed effects & Yes & Yes & Yes & Yes & Yes & Yes \\
\hline Cluster & Bank & Bank & Bank & Bank & Bank & Bank \\
\hline$\beta_{1}+\beta_{3}$ & -.27 & .77 & -.74 & .48 & -.57 & -.28 \\
\hline $\mathrm{p}$-value of test $\left(\beta_{1}+\beta_{3}=0\right)$ & .03 & .09 & .01 & .04 & .02 & .74 \\
\hline $\mathrm{p}$-value of test $\left(\beta_{1}+\beta_{2}=0\right)$ & .00 & .11 & .00 & .11 & .01 & .76 \\
\hline p-value of test $\left(\beta_{3}+\beta_{4}=0\right)$ & .16 & .12 & .93 & .12 & .32 & .29 \\
\hline
\end{tabular}


Table 4: Capital (requirements) and credit supply: aggregate effects

This table contains firm-level estimation results. In particular, we regress three different firm credit growth measures on (regulatory) capital ratios. In column 1 , the dependent variable is the growth in aggregate firm credit obtained by all banks in the SREP sample. In column 2, the dependent variable is the growth in firm-level credit obtained from all banks (hence including credit from non-SREP banks). In column 3, we examine firm-level credit growth obtained from non-SREP banks. Finally, in column 4, we use the share of credit by SREP banks in total firm credit as a dependent variable. Using data at the firm level, we analyze whether the drop in credit because of stricter capital requirements can be offset by banks with lower requirements or by banks not supervised by the National Bank of Belgium. More specifically, we run the following regression for these four different dependent variables:

Credit growth (Quarterly) $f, t=\beta_{1} *$ Required capital ratio $_{b, t-1}+\beta_{2} *$ Previous year required capital ratio $_{b, t-5}+\beta_{3} *$ Actual capital ratio $_{b, t-1}+\hat{\beta}_{4} *$ Previous year actual capital ratio $_{b, t-5}+\gamma *$ Bank controls $_{b, t-1}+\delta *$ Firm controls $_{f, t-1}+\epsilon_{f, t}$

Besides the variables of interest (which are reported in bold), the equation includes control variables, which are weighted averages using the credit shares at the firm-bank level as weights. They are: the natural logarithm of total assets, quarterly growth in common equity, quarterly growth in deposits, quarterly growth in total assets, quarterly return on equity and firms' probability of default. All bank variables have been lagged by one quarter such that they are in predetermined with respect to next quarter's credit growth. Firm controls are imputed fixed effects obtained from column 1 of Table 1. In particular, firm demand is now controlled for by including the estimated fixed effect from column 1 of Table 3. Weighted average estimated bank fixed effects (from column 1 of Table 3), which are firm-specific because of the weights, are also included. Standard errors are clustered at the industry-location-size-time (ILST) level.

\begin{tabular}{|c|c|c|c|c|}
\hline \multirow[b]{2}{*}{ VARIABLES } & \multicolumn{3}{|c|}{ Firm-level credit growth } & \multirow{2}{*}{$\begin{array}{c}\text { Share of credit } \\
\text { SREP } \\
\text { banks/All } \\
\text { Banks } \\
\end{array}$} \\
\hline & SREP banks & All banks & $\begin{array}{l}\text { Non-SREP } \\
\text { banks }\end{array}$ & \\
\hline Required capital ratio & $\begin{array}{c}-0.102^{* * *} \\
(0.024)\end{array}$ & $\begin{array}{c}-0.094^{* * *} \\
(0.024)\end{array}$ & $\begin{array}{c}0.187 \\
(0.229)\end{array}$ & $\begin{array}{c}-0.016^{*} \\
(0.008)\end{array}$ \\
\hline Previous year required capital ratio & $\begin{array}{c}-0.169^{* * *} \\
(0.020)\end{array}$ & $\begin{array}{c}-0.170^{* * *} \\
(0.020)\end{array}$ & $\begin{array}{c}0.058 \\
(0.206)\end{array}$ & $\begin{array}{c}0.008 \\
(0.007)\end{array}$ \\
\hline Actual capital ratio & $\begin{array}{c}-0.092^{* * *} \\
(0.011)\end{array}$ & $\begin{array}{c}-0.093^{* * *} \\
(0.011)\end{array}$ & $\begin{array}{l}-0.004 \\
(0.102)\end{array}$ & $\begin{array}{c}0.015^{* * *} \\
(0.003)\end{array}$ \\
\hline Previous year actual capital ratio & $\begin{array}{c}-0.023^{* *} \\
(0.010)\end{array}$ & $\begin{array}{l}-0.020^{*} \\
(0.011)\end{array}$ & $\begin{array}{c}0.050 \\
(0.100)\end{array}$ & $\begin{array}{c}0.002 \\
(0.003)\end{array}$ \\
\hline (lagged) Log total assets & $\begin{array}{c}0.010 * * * \\
(0.001)\end{array}$ & $\begin{array}{c}0.010^{* * *} \\
(0.001)\end{array}$ & $\begin{array}{c}0.007 * \\
(0.004)\end{array}$ & $\begin{array}{c}0.000 \\
(0.000)\end{array}$ \\
\hline (lagged) Quarterly growth in common equity & $\begin{array}{c}-0.045^{* * *} \\
(0.005)\end{array}$ & $\begin{array}{c}-0.041^{* * *} \\
(0.005)\end{array}$ & $\begin{array}{c}0.049 \\
(0.042)\end{array}$ & $\begin{array}{c}-0.002^{* *} \\
(0.001)\end{array}$ \\
\hline (lagged) Quarterly growth in deposits & $\begin{array}{c}0.006^{*} \\
(0.003)\end{array}$ & $\begin{array}{c}0.004 \\
(0.003)\end{array}$ & $\begin{array}{l}-0.062 \\
(0.038)\end{array}$ & $\begin{array}{c}0.003 * * * \\
(0.001)\end{array}$ \\
\hline (lagged) Quarterly growth in assets & $\begin{array}{c}-0.011^{* *} \\
(0.005)\end{array}$ & $\begin{array}{l}-0.006 \\
(0.005)\end{array}$ & $\begin{array}{c}0.093^{* *} \\
(0.046)\end{array}$ & $\begin{array}{l}-0.002 \\
(0.001)\end{array}$ \\
\hline (lagged) Quarterly return on equity & $\begin{array}{c}0.013^{* * *} \\
(0.003)\end{array}$ & $\begin{array}{c}0.012^{* * *} \\
(0.003)\end{array}$ & $\begin{array}{c}0.001 \\
(0.027)\end{array}$ & $\begin{array}{l}-0.001 \\
(0.001)\end{array}$ \\
\hline Default probability & $\begin{array}{c}-0.039 * * * \\
(0.001)\end{array}$ & $\begin{array}{c}-0.0389^{* * *} \\
(0.001)\end{array}$ & $\begin{array}{l}-0.013 \\
(0.012)\end{array}$ & $\begin{array}{c}0.001^{* *} \\
(0.001)\end{array}$ \\
\hline Observations & 475,770 & 475,770 & 17,296 & 471,853 \\
\hline R-squared & 0.56 & 0.55 & 0.00 & 0.91 \\
\hline Cluster & ILST & ILST & ILST & ILST \\
\hline Firm demand & \multirow{2}{*}{\multicolumn{4}{|c|}{$\begin{array}{l}\text { estimated firm*time FE from column } 1 \text { of Table } 3 \\
\text { weighted average estimated Bank FE from column } 1 \text { of Table } 3\end{array}$}} \\
\hline Bank FE & & & & \\
\hline
\end{tabular}


Table 5: Required capital and credit supply: banks' cost of capital

This table contains estimation results from a regression relating quarterly growth in authorized credit to (regulatory) capital ratios. The required capital ratio also enters in interaction with a bank characteristic related to a bank's cost of capital. We add these interaction terms one-by-one in subsequent columns. More specifically, we run the following regression:

Credit growth (Quarterly) $)_{b, f, t}=\left(\beta_{1}+\beta_{1}^{M P} *\right.$ Monetary policy $_{t}+\beta_{1}^{B C} *$ Bank characteristic $\left._{b, t-1}\right) *$ Required capital ratio $_{b, t-1}+\beta_{2} *$ Previous year required capital ratio $b_{b, t-5}+\beta_{3} *$ Actual capital ratio ${ }_{b, t-1}+\beta_{4} *$ Previous year actual capital Ratio $_{b, t-5}+\gamma *$ Bank controls $_{b, t-1}+\nu_{b}+$ $\nu_{f, t}+\epsilon_{b, f, t}$

Besides the variables of interest (of which the coefficients are reported), the equation includes control variables (similar to the baseline regression) that have been lagged by one quarter. $\nu_{f, t}$ is a firm $\mathrm{x}$ time fixed effect that captures time-varying firm demand shifters. $\nu_{b}$ is a $b a n k$ fixed effect. We indicate which bank characteristic enters as interaction term in the row following the interaction term. They are, respectively, a proxy for bank size, bank credit risk, bank profits, equity growth and a dummy if a bank's regulatory capital buffer is small. Standard errors are clustered at bank level.

\begin{tabular}{|c|c|c|c|c|c|c|}
\hline VARIABLES & $\begin{array}{l}\text { Credit } \\
\text { growth }\end{array}$ & $\begin{array}{l}\text { Credit } \\
\text { growth }\end{array}$ & $\begin{array}{l}\text { Credit } \\
\text { growth }\end{array}$ & $\begin{array}{l}\text { Credit } \\
\text { growth }\end{array}$ & $\begin{array}{l}\text { Credit } \\
\text { growth }\end{array}$ & $\begin{array}{l}\text { Credit } \\
\text { growth }\end{array}$ \\
\hline Required capital ratio & $\begin{array}{c}-0.201^{* *} \\
(0.092)\end{array}$ & $\begin{array}{c}-0.184^{*} \\
(0.100)\end{array}$ & $\begin{array}{c}-0.267^{* *} \\
(0.095)\end{array}$ & $\begin{array}{c}-0.202^{*} \\
(0.101)\end{array}$ & $\begin{array}{c}-0.211^{*} \\
(0.100)\end{array}$ & $\begin{array}{c}-0.251^{* *} \\
(0.099)\end{array}$ \\
\hline Required capital ratio $\mathrm{x}$ Monetary policy & $\begin{array}{c}-0.161^{* *} \\
(0.075)\end{array}$ & $\begin{array}{c}-0.163^{* *} \\
(0.074)\end{array}$ & $\begin{array}{l}-0.145 \\
(0.083)\end{array}$ & $\begin{array}{c}-0.156^{* *} \\
(0.067)\end{array}$ & $\begin{array}{c}-0.191^{* *} \\
(0.078)\end{array}$ & $\begin{array}{c}-0.214^{* *} \\
(0.078)\end{array}$ \\
\hline Required capital ratio $\mathrm{x}$ Bank characteristic & & $\begin{array}{l}0.058^{*} \\
(0.029)\end{array}$ & $\begin{array}{c}-0.045^{*} \\
(0.024)\end{array}$ & $\begin{array}{c}0.111^{*} \\
(0.062)\end{array}$ & $\begin{array}{c}0.123^{* * *} \\
(0.038)\end{array}$ & $\begin{array}{c}0.234^{* *} \\
(0.104)\end{array}$ \\
\hline Previous year required capital ratio & $\begin{array}{c}-0.284^{* * *} \\
(0.055)\end{array}$ & $\begin{array}{c}-0.287 * * * \\
(0.054)\end{array}$ & $\begin{array}{c}-0.286 * * * \\
(0.051)\end{array}$ & $\begin{array}{c}-0.297^{* * *} \\
(0.060)\end{array}$ & $\begin{array}{c}-0.314^{* * *} \\
(0.063)\end{array}$ & $\begin{array}{c}-0.472^{* * *} \\
(0.096)\end{array}$ \\
\hline Actual capital ratio & $\begin{array}{c}-0.219^{* *} \\
(0.094)\end{array}$ & $\begin{array}{c}-0.217^{* *} \\
(0.095)\end{array}$ & $\begin{array}{c}-0.211^{* *} \\
(0.095)\end{array}$ & $\begin{array}{c}-0.209 * * \\
(0.089)\end{array}$ & $\begin{array}{c}-0.254^{* *} \\
(0.106)\end{array}$ & $\begin{array}{c}-0.295^{* *} \\
(0.101)\end{array}$ \\
\hline Previous year actual capital ratio & $\begin{array}{c}-0.031 \\
(0.054)\end{array}$ & $\begin{array}{l}-0.029 \\
(0.054)\end{array}$ & $\begin{array}{l}-0.052 \\
(0.051)\end{array}$ & $\begin{array}{l}-0.015 \\
(0.050)\end{array}$ & $\begin{array}{l}-0.028 \\
(0.047)\end{array}$ & $\begin{array}{l}-0.075 \\
(0.070)\end{array}$ \\
\hline (lagged) Bank characteristic & & $\begin{array}{l}\text { Log total } \\
\text { assets }\end{array}$ & $\begin{array}{l}\text { Loan loss } \\
\text { provisions to } \\
\text { total loans }\end{array}$ & $\begin{array}{l}\text { Return on } \\
\text { equity }\end{array}$ & $\begin{array}{c}\text { Quarterly } \\
\text { growth in } \\
\text { common } \\
\text { equity }\end{array}$ & Small buffer \\
\hline Observations & $1,022,297$ & $1,022,297$ & $1,022,297$ & $1,022,297$ & $1,022,297$ & $1,022,297$ \\
\hline R-squared & 0.47 & 0.47 & 0.47 & 0.47 & 0.47 & 0.47 \\
\hline Firm*time fixed effects & Yes & Yes & Yes & Yes & Yes & Yes \\
\hline Bank fixed effects & Yes & Yes & Yes & Yes & Yes & Yes \\
\hline Bank controls & Yes & Yes & Yes & Yes & Yes & Yes \\
\hline Cluster & Bank & Bank & Bank & Bank & Bank & Bank \\
\hline
\end{tabular}


Table 6: Required capital and credit supply: banks' business models

This table contains estimation results from a regression relating quarterly growth in authorized credit to (regulatory) capital ratios. The required capital ratio also enters in interaction with a bank characteristic related to a bank's business model. We add these interaction terms one by one in subsequent columns. More specifically, we run the following regression:

Credit growth (Quarterly) $)_{b, f, t}=\left(\beta_{1}+\beta_{1}^{M P} *\right.$ Monetary policy $_{t}+\beta_{1}^{B C} *$ Bank characteristic $\left._{b, t-1}\right) *$ Required capital ratio $_{b, t-1}+$ $\beta_{2} *$ Previous year required capital ratio $_{b, t-5}+\beta_{3} *$ Actual capital ratio $b_{b, t-1}+\beta_{4} *$ Previous year actual capital Ratio $_{b, t-5}+\gamma *$ Bank controls ${ }_{b, t-1}+\nu_{b}+\nu_{f, t}+\epsilon_{b, f, t}$

Besides the variables of interest (of which the coefficients are reported), the equation includes control variables (similar to the baseline regression) that have been lagged one quarter. $\nu_{f, t}$ is a firm $\mathrm{x}$ time fixed effect that captures time-varying firm demand shifters. $\nu_{b}$ is a bank fixed effect. We indicate which bank characteristic enters as interaction term in the row following the interaction term. They are, respectively, bank asset growth, the share of retail deposits funding in deposits, the share of interbank funding and the share of interest income in total income. Standard errors are clustered at bank level.

\begin{tabular}{|c|c|c|c|c|}
\hline VARIABLES & Credit growth & Credit growth & Credit growth & Credit growth \\
\hline Required capital ratio & $\begin{array}{c}-0.207^{*} \\
(0.105)\end{array}$ & $\begin{array}{l}-0.078 \\
(0.123)\end{array}$ & $\begin{array}{c}-0.170^{*} \\
(0.093)\end{array}$ & $\begin{array}{c}-0.167^{*} \\
(0.086)\end{array}$ \\
\hline Required capital ratio * Monetary policy & $\begin{array}{c}-0.166^{*} \\
(0.082)\end{array}$ & $\begin{array}{c}-0.252^{* *} \\
(0.089)\end{array}$ & $\begin{array}{c}-0.190 * * \\
(0.083)\end{array}$ & $\begin{array}{c}-0.197^{* *} \\
(0.074)\end{array}$ \\
\hline Required capital ratio * Bank characteristic & $\begin{array}{l}0.008 \\
(0.053)\end{array}$ & $\begin{array}{l}-0.002 \\
(0.031)\end{array}$ & $\begin{array}{l}-0.011 \\
(0.068)\end{array}$ & $\begin{array}{c}-0.084^{* *} \\
(0.035)\end{array}$ \\
\hline Previous year required capital ratio & $\begin{array}{c}-0.287^{* * * *} \\
(0.058)\end{array}$ & $\begin{array}{c}-0.364 * * * \\
(0.104)\end{array}$ & $\begin{array}{c}-0.252^{* * * *} \\
(0.062)\end{array}$ & $\begin{array}{c}-0.274^{* * * *} \\
(0.043)\end{array}$ \\
\hline Actual capital ratio & $\begin{array}{c}-0.221^{* *} \\
(0.096)\end{array}$ & $\begin{array}{c}-0.269^{* *} \\
(0.114)\end{array}$ & $\begin{array}{c}-0.202^{* *} \\
(0.093)\end{array}$ & $\begin{array}{c}-0.215^{* *} \\
(0.088)\end{array}$ \\
\hline Previous year actual capital ratio & $\begin{array}{l}-0.032 \\
(0.052)\end{array}$ & $\begin{array}{l}-0.067 \\
(0.074)\end{array}$ & $\begin{array}{l}-0.035 \\
(0.064)\end{array}$ & $\begin{array}{l}-0.039 \\
(0.047)\end{array}$ \\
\hline (lagged) Bank characteristic & $\begin{array}{l}\text { Quarterly } \\
\text { growth in } \\
\text { assets }\end{array}$ & $\begin{array}{l}\text { Retail deposit } \\
\text { share }\end{array}$ & $\begin{array}{c}\text { Interbank } \\
\text { funding share }\end{array}$ & $\begin{array}{c}\text { Interest } \\
\text { income share }\end{array}$ \\
\hline Observations & $1,022,297$ & $1,022,297$ & $1,022,297$ & $1,022,297$ \\
\hline R-squared & 0.47 & 0.47 & 0.47 & 0.47 \\
\hline Firm*time fixed effects & Yes & Yes & Yes & Yes \\
\hline Bank fixed effects & Yes & Yes & Yes & Yes \\
\hline Bank controls & Yes & Yes & Yes & Yes \\
\hline Cluster & Bank & Bank & Bank & Bank \\
\hline
\end{tabular}


Table 7: Required capital and credit supply: heterogeneity due to firm characteristics

This table contains estimation results from a regression relating quarterly growth in authorized credit to (regulatory) capital ratios. The required capital ratio also enters in interaction with various firm characteristics. We add these interaction terms one by one in subsequent columns. More specifically, we run the following regression:

Credit growth (Quarterly) $)_{b, f, t}=\left(\beta_{1}+\beta_{1}^{M P} *\right.$ Monetary policy $_{t}+\beta_{1}^{F C} *$ Firm characteristic $\left._{b, t-1}\right) *$ Required capital ratio $_{b, t-1}+\beta_{2} *$ Previous year required capital ratio $b_{b, t-5}+\beta_{3} *$ Actual capital ratio $_{b, t-1}+\beta_{4} *$ Previous year actual capital Ratio $_{b, t-5}+\gamma * \mathrm{Bank}$ controls $s_{b, t-1}+\nu_{b}+$ $\nu_{f, t}+\epsilon_{b, f, t}$

Besides the variables of interest (of which the coefficients are reported), the equation includes control variables (similar to the baseline regression) that have been lagged by one quarter. $\nu_{f, t}$ is a firm $\mathrm{x}$ time fixed effect that captures time-varying firm demand shifters. $\nu_{b}$ is a bank fixed effect. We indicate which firm characteristic enters as interaction term in the row following the interaction term. They are, respectively, a proxy for firm size, Altman Z, firm financial leverage, the collateralization rate, firm cost of borrowing, firm age and the length of the bank-firm relationship. Standard errors are clustered at bank level.

\begin{tabular}{|c|c|c|c|c|c|c|c|}
\hline VARIABLES & $\begin{array}{l}\text { Credit } \\
\text { growth }\end{array}$ & $\begin{array}{l}\text { Credit } \\
\text { growth }\end{array}$ & $\begin{array}{l}\text { Credit } \\
\text { growth }\end{array}$ & $\begin{array}{l}\text { Credit } \\
\text { growth }\end{array}$ & $\begin{array}{l}\text { Credit } \\
\text { growth }\end{array}$ & $\begin{array}{l}\text { Credit } \\
\text { growth }\end{array}$ & $\begin{array}{l}\text { Credit } \\
\text { growth }\end{array}$ \\
\hline Required capital ratio & $\begin{array}{l}-0.159 \\
(0.105)\end{array}$ & $\begin{array}{c}-0.186^{*} \\
(0.101)\end{array}$ & $\begin{array}{c}-0.187^{*} \\
(0.101)\end{array}$ & $\begin{array}{c}-0.238^{* *} \\
(0.092)\end{array}$ & $\begin{array}{c}-0.193^{* *} \\
(0.089)\end{array}$ & $\begin{array}{l}-0.178 \\
(0.103)\end{array}$ & $\begin{array}{c}-0.327^{* * *} \\
(0.093)\end{array}$ \\
\hline Required capital ratio x Monetary policy & $\begin{array}{c}-0.178^{* *} \\
(0.072)\end{array}$ & $\begin{array}{c}-0.173^{* *} \\
(0.073)\end{array}$ & $\begin{array}{c}-0.174^{* *} \\
(0.074)\end{array}$ & $\begin{array}{c}-0.136^{*} \\
(0.072)\end{array}$ & $\begin{array}{c}-0.158^{* *} \\
(0.070)\end{array}$ & $\begin{array}{c}-0.173^{* *} \\
(0.073)\end{array}$ & $\begin{array}{l}-0.119 \\
(0.074)\end{array}$ \\
\hline Required capital $\times$ Firm characteristic & $\begin{array}{c}-0.243^{* * *} \\
(0.040)\end{array}$ & $\begin{array}{c}0.069^{* *} \\
(0.029)\end{array}$ & $\begin{array}{c}-0.103^{* * *} \\
(0.017)\end{array}$ & $\begin{array}{c}0.320^{* *} \\
(0.137)\end{array}$ & $\begin{array}{c}0.059^{* * *} \\
(0.011)\end{array}$ & $\begin{array}{c}-0.152^{* * *} \\
(0.025)\end{array}$ & $\begin{array}{c}0.714^{* * *} \\
(0.106)\end{array}$ \\
\hline Previous year required capital ratio & $\begin{array}{c}-0.261 * * * \\
(0.071)\end{array}$ & $\begin{array}{c}-0.269 * * * \\
(0.065)\end{array}$ & $\begin{array}{c}-0.269^{* * *} \\
(0.065)\end{array}$ & $\begin{array}{c}-0.309^{* * *} \\
(0.072)\end{array}$ & $\begin{array}{c}-0.289 * * * \\
(0.069)\end{array}$ & $\begin{array}{c}-0.267^{* * *} \\
(0.068)\end{array}$ & $\begin{array}{c}-0.270^{* * *} \\
(0.057)\end{array}$ \\
\hline Actual capital ratio & $\begin{array}{c}-0.213^{* *} \\
(0.098)\end{array}$ & $\begin{array}{c}-0.216^{* *} \\
(0.097)\end{array}$ & $\begin{array}{c}-0.216^{* *} \\
(0.097)\end{array}$ & $\begin{array}{c}-0.230^{* *} \\
(0.103)\end{array}$ & $\begin{array}{c}-0.200^{* *} \\
(0.088)\end{array}$ & $\begin{array}{c}-0.215^{* *} \\
(0.098)\end{array}$ & $\begin{array}{c}-0.233^{* *} \\
(0.093)\end{array}$ \\
\hline Previous year actual capital ratio & $\begin{array}{l}-0.027 \\
(0.065)\end{array}$ & $\begin{array}{l}-0.023 \\
(0.060)\end{array}$ & $\begin{array}{l}-0.023 \\
(0.060)\end{array}$ & $\begin{array}{l}-0.028 \\
(0.055)\end{array}$ & $\begin{array}{l}-0.019 \\
(0.056)\end{array}$ & $\begin{array}{l}-0.025 \\
(0.063)\end{array}$ & $\begin{array}{l}-0.038 \\
(0.056)\end{array}$ \\
\hline (lagged) Firm characteristic & Firm size & Altman Z & $\begin{array}{l}\text { Financial } \\
\text { leverage }\end{array}$ & $\begin{array}{c}\text { Collaterliza- } \\
\text { tion } \\
\text { rate }\end{array}$ & $\begin{array}{c}\text { Cost of } \\
\text { borrowing }\end{array}$ & Firm age & $\begin{array}{l}\text { Relation- } \\
\text { ship } \\
\text { length }\end{array}$ \\
\hline Observations & 969,700 & 969,626 & 969,700 & $1,022,297$ & 874,109 & 969,700 & $1,022,293$ \\
\hline R-squared & 0.47 & 0.47 & 0.47 & 0.47 & 0.46 & 0.47 & 0.47 \\
\hline Firm*time fixed effects & Yes & Yes & Yes & Yes & Yes & Yes & Yes \\
\hline Bank fixed effects & Yes & Yes & Yes & Yes & Yes & Yes & Yes \\
\hline Bank controls & Yes & Yes & Yes & Yes & Yes & Yes & Yes \\
\hline Cluster & Bank & Bank & Bank & Bank & Bank & Bank & Bank \\
\hline
\end{tabular}


Table 8: Capital (requirements) and credit supply: residual of required capital

This table contains estimation results from a regression relating various dimensions of credit growth to (regulatory) capital ratios. Compared to the baseline regression, we use the residual required capital ratio, which is the capital requirement orthogonalized with respect to current and lagged balance sheet information. The results of the first stage regression to obtain the residuals are reported in the appendix (Table A3). In the second stage, we run the following regression for six different dependent variables:

Credit conditions (Quarterly) $b, f, t=\beta_{1} *$ Residual required capital ratio ${ }_{b, t-1}+\beta_{2} *$ Previous year required capital ratio $_{b, t-5}+\beta_{3} *$ Actual capital ratio ${ }_{b, t-1}+\beta_{4} *$ Previous year actual capital ratio ${ }_{b, t-5}+\gamma *$ Bank controls $_{b, t-1}+\nu_{b}+\nu_{f, t}+\epsilon_{b, f, t}$

Besides the variables of interest, the equation includes control variables, which are: the natural logarithm of total assets, quarterly growth in common equity, quarterly growth in deposits, quarterly growth in total assets and quarterly return on equity. In all regresions, we also control for a bank-specific assessment of the firm's default probability. All bank variables have been lagged by one quarter such that they are predetermined with respect to next quarter's credit growth at the bank-firm level. In addition, we also control for a firm $\mathrm{x}$ time fixed effect $\left(\nu_{f, t}\right)$ that captures time-varying firm demand shifters and a bank fixed effect $\left(\nu_{b}\right)$. Standard errors are clustered at bank level. At the bottom of the table, we also provide information on the p-values of various tests on the coefficients of interest.

\begin{tabular}{|c|c|c|c|c|c|c|}
\hline VARIABLES & $\begin{array}{c}(1) \\
\text { Credit } \\
\text { growth }\end{array}$ & $\begin{array}{l}\text { Large drop } \\
\text { in credit }\end{array}$ & $\begin{array}{c}3) \\
\text { New } \\
\text { bank-firm } \\
\text { relation- } \\
\text { ships }\end{array}$ & $\begin{array}{l}\text { Utilization } \\
\text { rate }\end{array}$ & $\begin{array}{c}(5) \\
\text { Credit } \\
\text { growth - } \\
\text { Term Loans }\end{array}$ & $\begin{array}{l}\text { Collateral } \\
\text { rate }\end{array}$ \\
\hline Residual required capital ratio & $\begin{array}{c}-0.252^{*} \\
(0.124)\end{array}$ & $\begin{array}{c}0.366 \\
(0.305)\end{array}$ & $\begin{array}{c}-0.872^{* * *} \\
(0.210)\end{array}$ & $\begin{array}{l}0.261^{*} \\
(0.133)\end{array}$ & $\begin{array}{c}-0.578^{* *} \\
(0.265)\end{array}$ & $\begin{array}{l}1.137^{* *} \\
(0.477)\end{array}$ \\
\hline Previous year required capital ratio & $\begin{array}{c}-0.275^{* * *} \\
(0.065)\end{array}$ & $\begin{array}{l}0.403^{*} \\
(0.202)\end{array}$ & $\begin{array}{c}-0.875^{* * *} \\
(0.185)\end{array}$ & $\begin{array}{c}0.087 \\
(0.132)\end{array}$ & $\begin{array}{c}-0.334^{* *} \\
(0.133)\end{array}$ & $\begin{array}{l}-0.706 \\
(0.577)\end{array}$ \\
\hline Actual capital ratio & $\begin{array}{c}-0.162^{* *} \\
(0.064)\end{array}$ & $\begin{array}{c}0.448^{* *} \\
(0.186)\end{array}$ & $\begin{array}{c}0.034 \\
(0.086)\end{array}$ & $\begin{array}{c}0.202 * * \\
(0.074)\end{array}$ & $\begin{array}{c}-0.313^{* *} \\
(0.143)\end{array}$ & $\begin{array}{l}-0.683 \\
(0.408)\end{array}$ \\
\hline Previous year actual capital ratio & $\begin{array}{c}-0.023 \\
(0.059)\end{array}$ & $\begin{array}{c}-0.041 \\
(0.071)\end{array}$ & $\begin{array}{l}-0.061 \\
(0.100)\end{array}$ & $\begin{array}{l}0.005 \\
(0.073)\end{array}$ & $\begin{array}{c}0.017 \\
(0.153)\end{array}$ & $\begin{array}{c}0.176 \\
(0.210)\end{array}$ \\
\hline (lagged) Log total assets & $\begin{array}{c}0.012 \\
(0.014)\end{array}$ & $\begin{array}{c}-0.038^{* *} \\
(0.017)\end{array}$ & $\begin{array}{c}-0.361^{* * * *} \\
(0.085)\end{array}$ & $\begin{array}{c}-0.003 \\
(0.010)\end{array}$ & $\begin{array}{c}0.008 \\
(0.020)\end{array}$ & $\begin{array}{c}0.134^{* * *} \\
(0.030)\end{array}$ \\
\hline (lagged) Quarterly growth in common equity & $\begin{array}{c}-0.042^{* *} \\
(0.015)\end{array}$ & $\begin{array}{c}0.045 \\
(0.025)\end{array}$ & $\begin{array}{c}0.010 \\
(0.014)\end{array}$ & $\begin{array}{c}0.047^{* * *} \\
(0.009)\end{array}$ & $\begin{array}{c}-0.091^{* * *} \\
(0.026)\end{array}$ & $\begin{array}{c}-0.023 \\
(0.035)\end{array}$ \\
\hline (lagged) Quarterly growth in deposits & $\begin{array}{c}0.007 \\
(0.006)\end{array}$ & $\begin{array}{c}0.014 \\
(0.011)\end{array}$ & $\begin{array}{c}-0.054^{* *} \\
(0.021)\end{array}$ & $\begin{array}{l}-0.016 \\
(0.015)\end{array}$ & $\begin{array}{l}-0.016 \\
(0.014)\end{array}$ & $\begin{array}{c}-0.059^{*} \\
(0.033)\end{array}$ \\
\hline (lagged) Quarterly growth in total assets & $\begin{array}{l}-0.019 \\
(0.013)\end{array}$ & $\begin{array}{c}0.057^{* * * *} \\
(0.018)\end{array}$ & $\begin{array}{c}0.094^{* * *} \\
(0.027)\end{array}$ & $\begin{array}{c}0.082^{* * *} \\
(0.018)\end{array}$ & $\begin{array}{c}0.042 \\
(0.027)\end{array}$ & $\begin{array}{c}-0.090^{* * *} \\
(0.016)\end{array}$ \\
\hline (lagged) Quarterly return on equity & $\begin{array}{c}0.027 \\
(0.019)\end{array}$ & $\begin{array}{l}-0.038 \\
(0.034)\end{array}$ & $\begin{array}{l}-0.036 \\
(0.033)\end{array}$ & $\begin{array}{l}-0.009 \\
(0.009)\end{array}$ & $\begin{array}{c}0.031 \\
(0.025)\end{array}$ & $\begin{array}{c}-0.016 \\
(0.026)\end{array}$ \\
\hline Default probability & $\begin{array}{c}-0.040^{* * *} \\
(0.006)\end{array}$ & $\begin{array}{l}0.032^{*} \\
(0.016)\end{array}$ & $\begin{array}{c}-0.015^{* * *} \\
(0.004)\end{array}$ & $\begin{array}{c}0.117^{* * *} \\
(0.016)\end{array}$ & $\begin{array}{c}-0.034^{* * *} \\
(0.009)\end{array}$ & $\begin{array}{c}0.291^{* * *} \\
(0.051)\end{array}$ \\
\hline Observations & $1,022,297$ & $1,022,297$ & $1,067,376$ & $1,067,376$ & 577,073 & $1,022,297$ \\
\hline R-squared & 0.47 & 0.50 & 0.51 & 0.58 & 0.48 & 0.54 \\
\hline Firm*time fixed effects & Yes & Yes & Yes & Yes & Yes & Yes \\
\hline Bank fixed effects & Yes & Yes & Yes & Yes & Yes & Yes \\
\hline Cluster & Bank & Bank & Bank & Bank & Bank & Bank \\
\hline$\beta_{1}+\beta_{3}$ & -.41 & .81 & -.84 & .46 & -.89 & .45 \\
\hline $\mathrm{p}$-value of test $\left(\beta_{1}+\beta_{3}=0\right)$ & .04 & .11 & 0 & .03 & .04 & .57 \\
\hline $\mathrm{p}$-value of test $\left(\beta_{1}+\beta_{2}=0\right)$ & .01 & .14 & .00 & .12 & .02 & .63 \\
\hline $\mathrm{p}$-value of test $\left(\beta_{3}+\beta_{4}=0\right)$ & .14 & .13 & .86 & .12 & .27 & .41 \\
\hline
\end{tabular}


Table 9: Capital (requirements) and credit supply: anticipation effects in Q4, timing and asymmetry

In this table, we examine some extensions of the baseline specification. In the first column, we examine whether there are anticipation effects of the new capital requirement which already affect credit supply in the fourth quarter of the year before they become binding. In the second column, we include these anticipation effects in a specification that further examines whether the impact of required capital on credit supply differs across the various quarters of the year. Finally, in the third column, we explore the role of non-linearities by interacting actual and required capital with a dummy that is one if the requirement has increased compared to the previous year. Besides the variables of interest (of which the coefficients are reported), the equation includes control variables, which are: the natural logarithm of total assets, quarterly growth in common equity, quarterly growth in deposits, quarterly growth in total assets and quarterly return on equity as well as firms' probability of default. All bank variables have been lagged one quarter such that they are predetermined with respect to next quarter's credit growth at the bank-firm level. In addition, we add a firm x time fixed effect that captures time-varying firm demand shifters and a bank fixed effect. Standard errors are clustered at bank level.

\begin{tabular}{|c|c|c|c|}
\hline VARIABLES & $\begin{array}{l}\text { Credit } \\
\text { growth }\end{array}$ & $\begin{array}{l}\text { Credit } \\
\text { growth }\end{array}$ & $\begin{array}{l}\text { Credit } \\
\text { growth }\end{array}$ \\
\hline Required capital ratio & $\begin{array}{c}-0.233^{* *} \\
(0.085)\end{array}$ & & $\begin{array}{l}-0.590^{*} \\
(0.321)\end{array}$ \\
\hline Previous year required capital ratio & $\begin{array}{l}-0.387 * * * \\
(0.086)\end{array}$ & $\begin{array}{c}-0.353^{* * *} \\
(0.083)\end{array}$ & $\begin{array}{l}-0.040 \\
(0.257)\end{array}$ \\
\hline Actual capital ratio & $\begin{array}{c}-0.164^{* *} \\
(0.067)\end{array}$ & $\begin{array}{c}-0.143^{* *} \\
(0.066)\end{array}$ & $\begin{array}{l}-0.045 \\
(0.140)\end{array}$ \\
\hline Previous year actual capital ratio & $\begin{array}{c}-0.081^{*} \\
(0.045)\end{array}$ & $\begin{array}{l}-0.055 \\
(0.045)\end{array}$ & $\begin{array}{l}-0.076 \\
(0.100)\end{array}$ \\
\hline Next quarter required capital ratio*I(quarter 4) & $\begin{array}{c}-0.571^{* * *} \\
(0.166)\end{array}$ & $\begin{array}{c}-0.283^{* * *} \\
(0.086)\end{array}$ & \\
\hline Required capital ratio*I(quarter 1$)$ & & $\begin{array}{c}-0.239 * * \\
(0.095)\end{array}$ & \\
\hline Required capital ratio*I(quarter 2 | quarter 3 ) & & $\begin{array}{l}-0.016 \\
(0.049)\end{array}$ & \\
\hline Required capital ratio*I(quarter 4$)$ & & $\begin{array}{c}-0.534^{* * *} \\
(0.134)\end{array}$ & \\
\hline Required capital ratio*I $\left(\operatorname{Req}_{t-1}>\operatorname{Req}_{t-5}\right)$ & & & $\begin{array}{c}0.310^{* *} \\
(0.111)\end{array}$ \\
\hline Actual capital ratio*I $\left(\operatorname{Req}_{t-1}>\operatorname{Req}_{t-5}\right)$ & & & $\begin{array}{c}-0.182^{* *} \\
(0.066)\end{array}$ \\
\hline Observations & 875421 & 875421 & 1022297 \\
\hline R-squared & 0.47 & 0.47 & 0.47 \\
\hline Firm*time fixed effects & Yes & Yes & Yes \\
\hline Bank fixed effects & Yes & Yes & Yes \\
\hline Bank controls & Yes & Yes & Yes \\
\hline Cluster & Bank & Bank & Bank \\
\hline
\end{tabular}


Table 10: Summary statistics: Aggregate balance sheet items

This table contains summary statistics on broad asset and liability classes. The quarterly growth rate is reported in panel A. The share in total assets is reported in panel B. The total number of observations is, in general, 124, and are unbalanced over 12 quarters (2013Q1 to 2015Q4) and concerns 14 banks. However, the number of observations can be less than 124, as not all banks have each type of asset or liability. Data are winsorized at the $2 \%$ level.

\begin{tabular}{|c|c|c|c|c|c|}
\hline & mean & $\begin{array}{l}\text { standard } \\
\text { deviation }\end{array}$ & $\begin{array}{c}5 \text { th } \\
\text { percentile }\end{array}$ & median & $\begin{array}{c}\text { 95th } \\
\text { percentile }\end{array}$ \\
\hline \multicolumn{6}{|l|}{ Panel A: Growth rates } \\
\hline Cash and interbank assets & 0.016 & 0.284 & -0.512 & -0.002 & 0.492 \\
\hline Mortgages & 0.027 & 0.066 & -0.034 & 0.016 & 0.159 \\
\hline Term loans (domestic) & 0.011 & 0.054 & -0.066 & 0.010 & 0.064 \\
\hline Term loans (foreign) & 0.022 & 0.218 & -0.349 & 0.000 & 0.511 \\
\hline Other Loans & 0.005 & 0.209 & -0.288 & 0.001 & 0.503 \\
\hline Securities & -0.004 & 0.059 & -0.073 & -0.007 & 0.112 \\
\hline Other assets & -0.022 & 0.128 & -0.304 & -0.010 & 0.139 \\
\hline Total assets (domestic) & 0.009 & 0.057 & -0.059 & 0.006 & 0.049 \\
\hline Total assets & 0.006 & 0.052 & -0.068 & 0.005 & 0.074 \\
\hline Interbank liabilities & -0.021 & 0.495 & -0.794 & -0.001 & 0.661 \\
\hline Retail deposits & 0.022 & 0.102 & -0.036 & 0.008 & 0.096 \\
\hline Wholesale deposits & -0.000 & 0.153 & -0.198 & -0.009 & 0.262 \\
\hline Other debt & -0.020 & 0.161 & -0.300 & -0.011 & 0.238 \\
\hline Total liabilities & 0.006 & 0.055 & -0.069 & 0.004 & 0.071 \\
\hline Common equity & 0.006 & 0.064 & -0.120 & 0.022 & 0.104 \\
\hline \multicolumn{6}{|c|}{ Panel B: Share in total assets } \\
\hline Cash and interbank assets & 0.121 & 0.125 & 0.014 & 0.101 & 0.533 \\
\hline Mortgages & 0.244 & 0.185 & 0.025 & 0.220 & 0.636 \\
\hline Term loans (domestic) & 0.204 & 0.119 & 0.006 & 0.196 & 0.403 \\
\hline Term loans (foreign) & 0.034 & 0.044 & 0.000 & 0.009 & 0.143 \\
\hline Other loans & 0.060 & 0.049 & 0.004 & 0.045 & 0.184 \\
\hline Securities & 0.253 & 0.094 & 0.088 & 0.260 & 0.397 \\
\hline Other assets & 0.091 & 0.064 & 0.019 & 0.060 & 0.199 \\
\hline Total assets (domestic) & 0.734 & 0.180 & 0.429 & 0.673 & 0.975 \\
\hline Total assets & 1.000 & 0.000 & 1.000 & 1.000 & 1.000 \\
\hline Interbank liabilities & 0.109 & 0.196 & 0.002 & 0.069 & 0.876 \\
\hline Retail deposits & 0.667 & 0.198 & 0.013 & 0.661 & 0.876 \\
\hline Wholesale deposits & 0.067 & 0.082 & 0.001 & 0.035 & 0.276 \\
\hline Other debt & 0.096 & 0.087 & 0.019 & 0.048 & 0.285 \\
\hline Total liabilities & 0.940 & 0.021 & 0.919 & 0.938 & 0.970 \\
\hline Common equity & 0.060 & 0.021 & 0.030 & 0.062 & 0.081 \\
\hline
\end{tabular}


Table 11: Capital requirements and growth of balance sheet items

This table contains estimation results from a regression relating growth rates of bank asset or funding classes to (regulatory) capital ratios. We use the residual required capital ratio, which is the capital requirement orthogonalized with respect to current and lagged balance sheet information (see Table A3 of the appendix). The table consists of two panels in which each row depicts the results of an equation. The dependent variables in panel A are growth rates of asset types, whereas they are growth rate of funding in panel B. More specifically, we run the following regression:

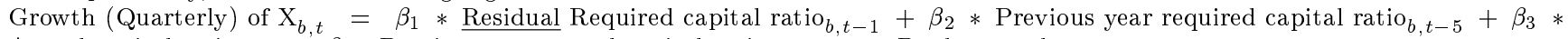
Actual capital ratio ${ }_{b, t-1}+\beta_{4} *$ Previous year actual capital ratio ${ }_{b, t-5}+\gamma *$ Bank controls $_{b, t-1}+\nu_{b}+\nu_{t}+\epsilon_{b, t}$

Besides the variables of interest (of which the point estimates and standard errors are reported), the equation includes control variables as well as bank and time fixed effects, i.e., $\left(\nu_{b}\right)$ and $\left(\nu_{t}\right)$ respectively. Moreover, the 15 regressions are estimated as a system of equations in order to allow for cross-equation error correlation. In addition, standard errors are clustered at bank level. In the last three columns, we report the number of observations in the regression, the regression R-squared as well as the p-value of the test of a constant buffer effect. That is, we test whether the impact of a joint increase in required and actual capital (thus holding the buffer between both constant) has a significant impact on the dependent variable. We thus test the hypothesis: $\beta_{1}+\beta_{3}=0$.

\begin{tabular}{|c|c|c|c|c|c|c|c|c|}
\hline $\begin{array}{l}\text { Equa- } \\
\text { tion }\end{array}$ & Dependent variable & $\begin{array}{l}\frac{\text { Residual }}{\text { required }} \\
\text { capital } \\
\text { ratio }\end{array}$ & $\begin{array}{l}\text { One year } \\
\text { lagged } \\
\text { required } \\
\text { capital } \\
\text { ratio }\end{array}$ & $\begin{array}{c}\text { Actual } \\
\text { capital ratio }\end{array}$ & $\begin{array}{c}\text { One year } \\
\text { lagged } \\
\text { actual } \\
\text { capital } \\
\text { ratio }\end{array}$ & $\begin{array}{l}\text { Obser- } \\
\text { vations }\end{array}$ & $\begin{array}{c}\text { R- } \\
\text { squared }\end{array}$ & $\begin{array}{c}\text { p-value } \\
\left(\beta_{1}+\right. \\
\left.\beta_{3}=0\right)\end{array}$ \\
\hline \multicolumn{9}{|c|}{ Panel A: Growth in asset types } \\
\hline$(1)$ & $\Delta \ln$ Cash and interbank assets & $\begin{array}{c}1.609 \\
(2.724)\end{array}$ & $\begin{array}{c}7.608^{* * *} \\
(0.792)\end{array}$ & $\begin{array}{c}1.956^{* *} \\
(0.874)\end{array}$ & $\begin{array}{l}-0.163 \\
(0.972)\end{array}$ & 124 & 0.48 & 0.26 \\
\hline$(2)$ & $\Delta \ln$ Mortgages & $\begin{array}{c}-0.853^{*} \\
(0.471)\end{array}$ & $\begin{array}{c}-0.865^{* *} \\
(0.388)\end{array}$ & $\begin{array}{c}-0.806^{* * *} \\
(0.282)\end{array}$ & $\begin{array}{c}-0.472 * * * \\
(0.173)\end{array}$ & 124 & 0.33 & 0.02 \\
\hline$(3)$ & $\Delta \ln$ Term loans (domestic) & $\begin{array}{c}-0.896^{*} \\
(0.495)\end{array}$ & $\begin{array}{c}0.184 \\
(0.643)\end{array}$ & $\begin{array}{c}-0.021 \\
(0.432)\end{array}$ & $\begin{array}{l}-0.072 \\
(0.284)\end{array}$ & 124 & 0.29 & 0.21 \\
\hline$(4)$ & $\Delta \ln$ Term loans (foreign) & $\begin{array}{c}-3.949 * * \\
(2.010)\end{array}$ & $\begin{array}{c}-5.125^{* *} \\
(2.149)\end{array}$ & $\begin{array}{c}-2.109^{* * *} \\
(0.697)\end{array}$ & $\begin{array}{l}-1.542 \\
(1.009)\end{array}$ & 112 & 0.42 & 0.00 \\
\hline$(5)$ & $\Delta \ln$ Other loans & $\begin{array}{c}-3.962^{* *} \\
(1.756)\end{array}$ & $\begin{array}{l}-1.252 \\
(2.985)\end{array}$ & $\begin{array}{l}-0.981 \\
(0.927)\end{array}$ & $\begin{array}{l}-0.097 \\
(1.245)\end{array}$ & 124 & 0.28 & 0.03 \\
\hline (6) & $\Delta \ln$ Securities & $\begin{array}{c}-1.117^{* * * *} \\
(0.377)\end{array}$ & $\begin{array}{c}-1.078^{*} \\
(0.558)\end{array}$ & $\begin{array}{c}-0.685^{* *} \\
(0.280)\end{array}$ & $\begin{array}{l}-0.316 \\
(0.215)\end{array}$ & 124 & 0.41 & 0.00 \\
\hline$(7)$ & $\Delta \ln$ Other assets & $\begin{array}{l}-1.911 \\
(1.683)\end{array}$ & $\begin{array}{c}3.309 \\
(2.036)\end{array}$ & $\begin{array}{l}-0.113 \\
(0.462)\end{array}$ & $\begin{array}{l}-0.160 \\
(0.442)\end{array}$ & 124 & 0.40 & 0.27 \\
\hline$(8)$ & $\Delta \ln$ Total assets (domestic) & $\begin{array}{c}-0.773^{* *} \\
(0.376)\end{array}$ & $\begin{array}{c}0.194 \\
(0.643)\end{array}$ & $\begin{array}{l}-0.045 \\
(0.316)\end{array}$ & $\begin{array}{l}-0.155 \\
(0.309)\end{array}$ & 124 & 0.29 & 0.18 \\
\hline$(9)$ & $\Delta \ln$ Total assets & $\begin{array}{c}-0.976 * * \\
(0.487)\end{array}$ & $\begin{array}{c}0.712 \\
(0.654)\end{array}$ & $\begin{array}{l}-0.341 \\
(0.273)\end{array}$ & $\begin{array}{l}-0.273 \\
(0.219)\end{array}$ & 124 & 0.39 & 0.03 \\
\hline \multicolumn{9}{|c|}{ Panel B: Growth in funding } \\
\hline$(10)$ & $\Delta \ln$ Interbank liabilities & $\begin{array}{c}6.342 \\
(6.269)\end{array}$ & $\begin{array}{c}6.765^{* * *} \\
(2.509)\end{array}$ & $\begin{array}{c}0.733 \\
(1.670)\end{array}$ & $\begin{array}{c}0.443 \\
(2.264)\end{array}$ & 122 & 0.37 & 0.26 \\
\hline$(11)$ & $\Delta \ln$ Retail deposits & $\begin{array}{c}-1.173^{*} \\
(0.680)\end{array}$ & $\begin{array}{l}-3.380 \\
(2.094)\end{array}$ & $\begin{array}{c}-0.831^{* *} \\
(0.414)\end{array}$ & $\begin{array}{l}-1.511 \\
(1.192)\end{array}$ & 124 & 0.37 & 0.03 \\
\hline$(12)$ & $\Delta \ln$ Wholesale deposits & $\begin{array}{c}-5.046^{* * *} \\
(1.738)\end{array}$ & $\begin{array}{c}0.131 \\
(1.610)\end{array}$ & $\begin{array}{l}-0.837 \\
(0.896)\end{array}$ & $\begin{array}{c}0.063 \\
(0.366)\end{array}$ & 124 & 0.30 & 0.01 \\
\hline (13) & $\Delta$ ln Other debt & $\begin{array}{l}-1.772 \\
(1.321)\end{array}$ & $\begin{array}{c}1.884 \\
(1.563)\end{array}$ & $\begin{array}{c}-0.923^{* *} \\
(0.410)\end{array}$ & $\begin{array}{l}-0.926 \\
(0.621)\end{array}$ & 124 & 0.38 & 0.04 \\
\hline (14) & $\Delta \ln$ Total liabilities & $\begin{array}{c}-1.070^{* *} \\
(0.507)\end{array}$ & $\begin{array}{c}0.782 \\
(0.677)\end{array}$ & $\begin{array}{l}-0.349 \\
(0.283)\end{array}$ & $\begin{array}{l}-0.281 \\
(0.234)\end{array}$ & 124 & 0.39 & 0.02 \\
\hline$(15)$ & $\Delta \ln$ Common equity & $\begin{array}{c}0.396 \\
(0.313)\end{array}$ & $\begin{array}{l}-0.031 \\
(0.414)\end{array}$ & $\begin{array}{c}-0.260^{*} \\
(0.137)\end{array}$ & $\begin{array}{l}-0.270 \\
(0.219)\end{array}$ & 124 & 0.49 & 0.69 \\
\hline
\end{tabular}


Appendix 
Table A1: Banks covered in the SREP vis-à-vis the other banks: comparing number of borrowers, volume of loans and assets

This table provides information on the number of borrowers, the total amount of corporate credit (in million euro), aggregate volume of total assets (in million euro) as well as the number of banks for two groups of banks. In the left panel, we report the information for the banks covered in the SREP (and hence the sample used in this paper). The middle panel provides information for the other banks. In the rightmost panel, we report the share of the "SREP" sample in the total sample for the number of borrowers as well as the volume of corporate credit and assets. The information is provided for each quarter in the sample used in the analysis, running from the first quarter of 2013 to the last of 2015 . The jump in the first quarter of 2014 is due to the inclusion in the SREP group as of 2014 of one of the four large banks in Belgium (as well as two other smaller banks).

\begin{tabular}{|c|c|c|c|c|c|c|c|c|c|c|c|c|c|}
\hline \multirow[b]{2}{*}{ Year } & \multirow[b]{2}{*}{$\begin{array}{l}\text { Quar- } \\
\text { ter }\end{array}$} & \multicolumn{4}{|c|}{ SREP banks } & \multicolumn{4}{|c|}{ Non-SREP banks } & \multicolumn{4}{|c|}{ Share of SREP banks in } \\
\hline & & $\begin{array}{l}\text { Number of } \\
\text { firm-bank } \\
\text { relation- } \\
\text { ships }\end{array}$ & $\begin{array}{c}\text { Aggregate } \\
\text { firm-bank } \\
\text { credit } \\
\text { exposure } \\
\text { (million } \\
\text { euro) }\end{array}$ & $\begin{array}{l}\text { Aggregate } \\
\text { total assets } \\
\text { (million } \\
\text { euro) }\end{array}$ & $\begin{array}{l}\text { Number } \\
\text { of banks }\end{array}$ & $\begin{array}{l}\text { Number of } \\
\text { firm-bank } \\
\text { relation- } \\
\text { ships }\end{array}$ & $\begin{array}{c}\text { Aggregate } \\
\text { firm-bank } \\
\text { credit } \\
\text { exposure } \\
\text { (million } \\
\text { euro) }\end{array}$ & $\begin{array}{l}\text { Aggregate } \\
\text { total assets } \\
\text { (million } \\
\text { euro) }\end{array}$ & $\begin{array}{l}\text { Number } \\
\text { of banks }\end{array}$ & $\begin{array}{l}\text { All } \\
\text { firm-bank } \\
\text { relation- } \\
\text { ships }\end{array}$ & $\begin{array}{c}\text { Aggregate } \\
\text { firm-bank } \\
\text { credit } \\
\text { exposure } \\
\text { (million } \\
\text { euro) }\end{array}$ & $\begin{array}{c}\text { Aggregate } \\
\text { total } \\
\text { assets } \\
\text { (million } \\
\text { euro) }\end{array}$ & $\begin{array}{c}\text { Total } \\
\text { number } \\
\text { of banks }\end{array}$ \\
\hline 2013 & Q1 & 298,956 & 96,922 & 628,056 & 11 & 83,013 & 32,622 & 214,481 & 17 & 0.78 & 0.75 & 0.75 & 0.39 \\
\hline 2013 & Q2 & 302,272 & 97,887 & 629,150 & 11 & 83,543 & 30,661 & 208,372 & 17 & 0.78 & 0.76 & 0.75 & 0.39 \\
\hline 2013 & Q4 & 305,951 & 96,932 & 578,778 & 11 & 83,851 & 30,769 & 193,217 & 17 & 0.78 & 0.76 & 0.75 & 0.39 \\
\hline 2014 & Q1 & 371,011 & 120,623 & 751,995 & 14 & 15,342 & 6,523 & 41,098 & 14 & 0.96 & 0.95 & 0.95 & 0.50 \\
\hline 2014 & Q2 & 369,473 & 120,984 & 767,089 & 14 & 15,012 & 6,354 & 39,450 & 14 & 0.96 & 0.95 & 0.95 & 0.50 \\
\hline 2014 & Q3 & 366,790 & 121,526 & 778,424 & 14 & 16,697 & 6,490 & 40,058 & 14 & 0.96 & 0.95 & 0.95 & 0.50 \\
\hline 2014 & Q4 & 373,748 & 133,141 & 777,075 & 14 & 16,581 & 6,442 & 39,118 & 14 & 0.96 & 0.95 & 0.95 & 0.50 \\
\hline 2015 & Q1 & 370,489 & 134,097 & 821,347 & 14 & 16,765 & 6,660 & 40,374 & 14 & 0.96 & 0.95 & 0.95 & 0.50 \\
\hline 2015 & Q2 & 369,956 & 136,132 & 788,704 & 14 & 16,811 & 6,658 & 40,946 & 14 & 0.96 & 0.95 & 0.95 & 0.50 \\
\hline 2015 & Q3 & 370,060 & 136,919 & 782,849 & 14 & 16,878 & 6,353 & 40,209 & 14 & 0.96 & 0.96 & 0.95 & 0.50 \\
\hline 2015 & Q4 & 369,152 & 141,002 & 754,160 & 14 & 16,731 & 6,414 & 39,886 & 13 & 0.96 & 0.96 & 0.95 & 0.52 \\
\hline
\end{tabular}


Table A2: Required capital and credit supply: robustness check on self-employed

This table contains the results of a robustness check concerning self-employed individuals with a registered corporate activity. We regress quarterly growth in authorized credit on (regulatory) capital ratios and add an interaction of required capital with firm size (column 1), a dummy if it concerns a firm with no additional employees, in that case I(self-employed) $=1$ (column 2 ) and the two aforementioned interactions jointly (column 3). Besides the variables of interest (of which the coefficients are reported), the equation includes control variables that have been lagged one quarter as well as the interaction between required capital and monetary policy. The equation also includes a firm $\mathrm{x}$ time fixed effect that captures time-varying firm demand shifters as well as a bank fixed effect. Standard errors are clustered at bank level.

\begin{tabular}{lccc}
\hline \hline VARIABLES & $\begin{array}{c}\text { Credit } \\
\text { growth }\end{array}$ & $\begin{array}{c}\text { Credit } \\
\text { growth }\end{array}$ & $\begin{array}{c}\text { Credit } \\
\text { growth }\end{array}$ \\
\hline Required capital ratio & -0.159 & $-0.241^{* *}$ & -0.168 \\
& $(0.105)$ & $(0.110)$ & $(0.114)$ \\
Previous year required capital ratio & $-0.261^{* * *}$ & $-0.267^{* * *}$ & $-0.261^{* * *}$ \\
& $(0.071)$ & $(0.066)$ & $(0.071)$ \\
Actual capital ratio & $-0.213^{* *}$ & $-0.215^{* *}$ & $-0.212^{* *}$ \\
& $(0.098)$ & $(0.097)$ & $(0.098)$ \\
Previous year actual capital ratio & -0.027 & -0.024 & -0.027 \\
& $(0.065)$ & $(0.062)$ & $(0.065)$ \\
Required capital ratio x Monetary policy & & & $-0.178^{* *}$ \\
& $-0.178^{* *}$ & $-0.176^{* *}$ & $(0.072)$ \\
Required capital ratio x ln(Total assets) & $(0.072)$ & $(0.073)$ & $-0.239^{* * *}$ \\
& $-0.243^{* * *}$ & & $(0.041)$ \\
Required capital ratio x I(Self-employed) & $(0.040)$ & & 0.031 \\
& & $0.175^{* *}$ & $(0.078)$ \\
& & $(0.074)$ & \\
\hline Observations & & 969,700 & 969,700 \\
R-squared & & 0.47 & 0.47 \\
Firm*time fixed effects & 969,700 & Yes & Yes \\
Bank fixed effects & 0.47 & Yes & Yes \\
Cluster & Yes & Bank & Bank \\
\hline \hline
\end{tabular}


Table A3: Residual Required capital ratio: first stage orthogonalization

This table contains estimation results from a regression of the required capital ratio on a large set of bank characteristics. These regressions serve the purpose of documenting that the Pillar 2 requirements are by and large independent of observed balance sheet characteristics. In column 2 (3), we include contemporaneous (lagged) values of the bank characteristics, whereas in column 4 we include both sets jointly. The first column is a regression of the capital requirements on bank fixed effects of which the R-squared serves as a benchmark for the additional explanatory power of the bank characteristics. In the last row of the table, we report the p-value of an F-test for the joint significance of the included regressors. The residuals of these regressions can then be considered as "non-balance-sheet-based" capital requirements and used to test whether the main results are robust to this first-stage orthogonalization. This additional test should provide further support for the causality of the documented relationships.

\begin{tabular}{|c|c|c|c|c|}
\hline VARIABLES & $\begin{array}{c}\text { Required } \\
\text { capital ratio }\end{array}$ & $\begin{array}{c}\text { Required } \\
\text { capital ratio }\end{array}$ & $\begin{array}{c}\text { Required } \\
\text { capital ratio }\end{array}$ & $\begin{array}{c}\text { Required } \\
\text { capital ratio }\end{array}$ \\
\hline Loans to total assets & & $\begin{array}{c}-0.062^{*} \\
(0.035)\end{array}$ & & $\begin{array}{l}-0.024 \\
(0.049)\end{array}$ \\
\hline Equity to total assets & & $\begin{array}{l}-0.011 \\
(0.121)\end{array}$ & & $\begin{array}{l}-0.481 \\
(0.486)\end{array}$ \\
\hline Deposits to total assets & & $\begin{array}{l}0.063 * \\
(0.033)\end{array}$ & & $\begin{array}{c}0.047 \\
(0.050)\end{array}$ \\
\hline Interbank liabilities to total assets & & $\begin{array}{c}0.024 \\
(0.026)\end{array}$ & & $\begin{array}{c}0.015 \\
(0.048)\end{array}$ \\
\hline Interest income share & & $\begin{array}{c}0.002 \\
(0.008)\end{array}$ & & $\begin{array}{c}0.001 \\
(0.008)\end{array}$ \\
\hline Quarterly return on equity & & $\begin{array}{l}-0.001 \\
(0.006)\end{array}$ & & $\begin{array}{l}-0.004 \\
(0.008)\end{array}$ \\
\hline Quarterly growth of total assets & & $\begin{array}{l}-0.013 \\
(0.015)\end{array}$ & & $\begin{array}{l}-0.049 \\
(0.041)\end{array}$ \\
\hline Quarterly growth of equity & & $\begin{array}{c}0.009 \\
(0.013)\end{array}$ & & $\begin{array}{c}0.043 \\
(0.034)\end{array}$ \\
\hline Quarterly growth of deposits & & $\begin{array}{c}0.002 \\
(0.006)\end{array}$ & & $\begin{array}{l}-0.004 \\
(0.008)\end{array}$ \\
\hline Default probability & & $\begin{array}{l}-0.006 \\
(0.030)\end{array}$ & $\begin{array}{c}-0.020 \\
(0.032)\end{array}$ & $\begin{array}{l}-0.012 \\
(0.034)\end{array}$ \\
\hline Lagged loans to total assets & & & $\begin{array}{c}-0.073^{*} \\
(0.037)\end{array}$ & $\begin{array}{l}-0.058 \\
(0.053)\end{array}$ \\
\hline Lagged equity to total assets & & & $\begin{array}{l}-0.002 \\
(0.104)\end{array}$ & $\begin{array}{c}0.500 \\
(0.459)\end{array}$ \\
\hline Lagged deposits to total assets & & & $\begin{array}{l}0.064^{*} \\
(0.037)\end{array}$ & $\begin{array}{c}0.026 \\
(0.050)\end{array}$ \\
\hline Lagged interbank liabilities to total assets & & & $\begin{array}{c}0.020 \\
(0.027)\end{array}$ & $\begin{array}{c}0.008 \\
(0.045)\end{array}$ \\
\hline Lagged interest income share & & & $\begin{array}{c}0.003 \\
(0.007)\end{array}$ & $\begin{array}{c}0.006 \\
(0.008)\end{array}$ \\
\hline Lagged quarterly return on equity & & & $\begin{array}{c}0.002 \\
(0.007)\end{array}$ & $\begin{array}{l}-0.001 \\
(0.008)\end{array}$ \\
\hline Lagged quarterly growth of total assets & & & $\begin{array}{c}0.008 \\
(0.013)\end{array}$ & $\begin{array}{c}0.014 \\
(0.015)\end{array}$ \\
\hline Lagged quarterly growth of equity & & & $\begin{array}{c}0.000 \\
(0.013)\end{array}$ & $\begin{array}{c}0.002 \\
(0.015)\end{array}$ \\
\hline Lagged quarterly growth of deposits & & & $\begin{array}{l}-0.003 \\
(0.005)\end{array}$ & $\begin{array}{l}-0.006 \\
(0.007)\end{array}$ \\
\hline Observations & 128 & 128 & 128 & 128 \\
\hline R-squared & 0.89 & 0.89 & 0.89 & 0.90 \\
\hline Bank dummies & Yes & Yes & Yes & Yes \\
\hline F-stat & & 0.677 & 0.482 & 0.573 \\
\hline
\end{tabular}


Table A4: Required capital and credit supply: opposite capital change

Compared with the table containing the baseline results (Table 3), we present results from using two alternative samples. In panel A, we only include firm-quarter observations for firms that simultaneously borrow from a bank with a strict increase in required capital ratio as well as a bank with a decrease in the required capital ratio. In panel $\mathrm{B}$, we additionaly include single-bank borrowers. The latter firms are pooled into groups based on industry, size and location and within each pool at least one firm is required to borrow from a bank with a strict increase in required capital ratio and at least one firm must borrow from a bank with a decrease in the required capital ratio. For each of these samples, we re-run the baseline regressions for six different dependent variables:

Credit conditions (Quarterly) ${ }_{b, f, t}=\beta_{1} *$ Required capital ratio $_{b, t-1}+\beta_{2} *$ Previous year required capital ratio $_{b, t-5}+\beta_{3} *$ Actual capital ratio r $_{b, t-1}+\beta_{4} *$ Previous year actual capital ratio $_{b, t-5}+\gamma *$ Bank controls $_{b, t-1}+\nu_{b}+\nu_{f, t}\left(\right.$ or $\left.\nu_{I L S, t}\right)+\epsilon_{b, f, t}$ Besides the variables of interest (of which the coefficients are reported), the equation includes control variables, which are: the natural logarithm of total assets, quarterly growth in common equity, quarterly growth in deposits, quarterly growth in total assets and quarterly return on equity. In all regresions, we also control for a bank-specific assessment of the firm's default probability. All bank variables have been lagged by one quarter such that they are in principle predetermined with respect to the next quarter's credit growth at the bank-firm level. In panel $\mathrm{A}, \nu_{f, t}$ is a firm $\mathrm{x}$ time fixed effect that captures time-varying firm demand shifters. In panel $\mathrm{B}$, which includes single bank borrowers, $\nu_{I L S, t}$ is a ILS x time fixed effect that captures time-varying firm demand shifters. ILS allows for the inclusion of single-bank borrowers, by creating groups (for each quarter separately) based on firms their industry, size and location. $\nu_{b}$ is a bank fixed effect. Standard errors are clustered at bank level.

\begin{tabular}{|c|c|c|c|c|c|c|}
\hline VARIABLES & $\begin{array}{l}\text { Credit } \\
\text { growth }\end{array}$ & $\begin{array}{l}\text { Large drop } \\
\text { in credit }\end{array}$ & $\begin{array}{c}\text { New } \\
\text { bank-firm } \\
\text { relation- } \\
\text { ships }\end{array}$ & $\begin{array}{l}\text { Utilization } \\
\text { rate }\end{array}$ & $\begin{array}{c}\text { Credit } \\
\text { growth - } \\
\text { Term loans }\end{array}$ & $\begin{array}{c}\text { Collateral } \\
\text { rate }\end{array}$ \\
\hline
\end{tabular}

Panel A: Multiple-bank borrowers

\begin{tabular}{|c|c|c|c|c|c|c|}
\hline Required capital ratio & $\begin{array}{c}-0.163^{*} \\
(0.080)\end{array}$ & $\begin{array}{c}0.465 \\
(0.301)\end{array}$ & $\begin{array}{c}-0.677^{* *} \\
(0.268)\end{array}$ & $\begin{array}{c}0.117 \\
(0.290)\end{array}$ & $\begin{array}{c}-0.524^{* * *} \\
(0.107)\end{array}$ & $\begin{array}{l}-0.101 \\
(0.513)\end{array}$ \\
\hline Previous year required capital ratio & $\begin{array}{c}-0.282^{* * *} \\
(0.058)\end{array}$ & $\begin{array}{c}0.617^{* * * *} \\
(0.200)\end{array}$ & $\begin{array}{c}-0.708 * * * \\
(0.218)\end{array}$ & $\begin{array}{c}0.237 \\
(0.193)\end{array}$ & $\begin{array}{c}-0.333^{* * *} \\
(0.090)\end{array}$ & $\begin{array}{l}-0.687 \\
(0.740)\end{array}$ \\
\hline Actual capital ratio & $\begin{array}{c}-0.179 * * * \\
(0.049)\end{array}$ & $\begin{array}{c}0.537^{* * * *} \\
(0.158)\end{array}$ & $\begin{array}{c}0.097 \\
(0.117)\end{array}$ & $\begin{array}{l}0.239 * \\
(0.128)\end{array}$ & $\begin{array}{c}-0.274^{* *} \\
(0.091)\end{array}$ & $\begin{array}{c}-1.565^{* *} \\
(0.568)\end{array}$ \\
\hline Previous year actual capital ratio & $\begin{array}{c}0.018 \\
(0.030)\end{array}$ & $\begin{array}{l}-0.096 \\
(0.078)\end{array}$ & $\begin{array}{l}-0.046 \\
(0.083)\end{array}$ & $\begin{array}{l}-0.007 \\
(0.099)\end{array}$ & $\begin{array}{c}0.164 \\
(0.101)\end{array}$ & $\begin{array}{l}-0.228 \\
(0.467)\end{array}$ \\
\hline Observations & 713,294 & 713,294 & 744,624 & 744,624 & 388,411 & 713,294 \\
\hline R-squared & 0.46 & 0.49 & 0.49 & 0.58 & 0.47 & 0.53 \\
\hline Sample & Multiples & Multiples & Multiples & Multiples & Multiples & Multiples \\
\hline Firm*time fixed effects & Yes & Yes & Yes & Yes & Yes & Yes \\
\hline Bank fixed effects & Yes & Yes & Yes & Yes & Yes & Yes \\
\hline Bank controls & Yes & Yes & Yes & Yes & Yes & Yes \\
\hline Cluster & Bank & Bank & Bank & Bank & Bank & Bank \\
\hline
\end{tabular}

Panel B: Single- and multiple-bank borrowers

\begin{tabular}{|c|c|c|c|c|c|c|}
\hline Required capital ratio & $\begin{array}{c}-0.217^{* *} \\
(0.094)\end{array}$ & $\begin{array}{c}0.431 \\
(0.257)\end{array}$ & $\begin{array}{c}-0.899^{* *} \\
(0.366)\end{array}$ & $\begin{array}{c}0.026 \\
(0.201)\end{array}$ & $\begin{array}{l}-0.244 \\
(0.150)\end{array}$ & $\begin{array}{c}0.287 \\
(0.513)\end{array}$ \\
\hline Previous year required capital ratio & $\begin{array}{c}-0.292^{* * *} \\
(0.074)\end{array}$ & $\begin{array}{c}0.633^{* *} \\
(0.229)\end{array}$ & $\begin{array}{c}-0.944^{* *} \\
(0.316)\end{array}$ & $\begin{array}{c}0.328 \\
(0.273)\end{array}$ & $\begin{array}{c}-0.256 * * \\
(0.105)\end{array}$ & $\begin{array}{l}-1.474 \\
(0.855)\end{array}$ \\
\hline Actual capital ratio & $\begin{array}{c}-0.169^{*} \\
(0.079)\end{array}$ & $\begin{array}{l}0.376^{*} \\
(0.192)\end{array}$ & $\begin{array}{c}0.185 \\
(0.128)\end{array}$ & $\begin{array}{c}0.073 \\
(0.155)\end{array}$ & $\begin{array}{c}-0.149^{*} \\
(0.079)\end{array}$ & $\begin{array}{c}-1.143^{*} \\
(0.548)\end{array}$ \\
\hline Previous year actual capital ratio & $\begin{array}{l}-0.071 \\
(0.087)\end{array}$ & $\begin{array}{l}-0.029 \\
(0.159)\end{array}$ & $\begin{array}{l}-0.132 \\
(0.153)\end{array}$ & $\begin{array}{l}-0.177 \\
(0.102)\end{array}$ & $\begin{array}{l}-0.048 \\
(0.175)\end{array}$ & $\begin{array}{l}-0.150 \\
(0.280)\end{array}$ \\
\hline Observations & $2,985,800$ & $2,985,800$ & $3,065,124$ & $3,065,124$ & $2,211,122$ & $2,985,800$ \\
\hline R-squared & 0.18 & 0.26 & 0.16 & 0.37 & 0.21 & 0.30 \\
\hline Sample & All & All & All & All & All & All \\
\hline ILS*time fixed effects & Yes & Yes & Yes & Yes & Yes & Yes \\
\hline Bank fixed effects & Yes & Yes & Yes & Yes & Yes & Yes \\
\hline Bank controls & Yes & Yes & Yes & Yes & Yes & Yes \\
\hline Cluster & Bank & Bank & Bank & Bank & Bank & Bank \\
\hline
\end{tabular}


Table A5: Capital requirements and growth of balance sheet items: robustness

This table contains estimation results from a regression relating growth rates of bank asset or funding classes to (regulatory) capital ratios. Unlike in Table 11 in the paper, we now use the Required capital ratio, rather than the residuals of a first-stage regression. The table consists of two panels in which each row depicts the results of an equation. The dependent variables in panel A are growth in asset types, whereas they are growth in funding in panel B. More specifically, we run the following regression:

Growth (Quarterly) of $\mathrm{X}_{b, t}=\beta_{1} *$ Required capital ratio ${ }_{b, t-1}+\beta_{2} *$ Previous year required capital ratio $_{b, t-5}+\beta_{3} *$ Actual capital ratio ${ }_{b, t-1}+\beta_{4} *$ Previous year actual capital ratio $_{b, t-5}+\gamma *$ Bank controls $_{b, t-1}+\nu_{b}+\nu_{t}+\epsilon_{b, t}$

Besides the variables of interest (of which the point estimates and standard errors are reported), the equation includes control variables as well as bank and time fixed effects, denoted $\nu_{b}$ and $\nu_{t}$ respectively. Moreover, the 15 regressions are estimated as a system of equations in order to allow for cross-equation error correlation. Standard errors are clustered at bank level. In the last three columns, we report the number of observations in the regression, the regression R-squared as well as the p-value of the test of a constant buffer effect. That is, we test whether the impact of a joint increase in required and actual capital (thus holding the buffer between both constant) has a significant impact on the dependent variable. We thus test the hypothesis: $\beta_{1}+\beta_{3}=0$.

\begin{tabular}{|c|c|c|c|c|c|c|c|c|}
\hline $\begin{array}{l}\text { Equa- } \\
\text { tion }\end{array}$ & Dependent variable & $\begin{array}{l}\text { Required } \\
\text { capital } \\
\text { ratio }\end{array}$ & $\begin{array}{l}\text { One year } \\
\text { lagged } \\
\text { required } \\
\text { capital } \\
\text { ratio }\end{array}$ & $\begin{array}{c}\text { Actual } \\
\text { capital ratio }\end{array}$ & $\begin{array}{c}\text { One year } \\
\text { lagged } \\
\text { actual } \\
\text { capital } \\
\text { ratio }\end{array}$ & $\begin{array}{l}\text { Obser- } \\
\text { vations }\end{array}$ & $\begin{array}{c}\text { R- } \\
\text { squared }\end{array}$ & $\begin{array}{c}\text { p-value } \\
\left(\beta_{1}+\right. \\
\left.\beta_{3}=0\right)\end{array}$ \\
\hline \multicolumn{9}{|c|}{ Panel A: Growth in asset types } \\
\hline (1) & $\Delta \ln$ Cash and interbank assets & $\begin{array}{c}0.434 \\
(2.718)\end{array}$ & $\begin{array}{c}7.378^{* * *} \\
(0.886)\end{array}$ & $\begin{array}{l}1.838^{* *} \\
(0.840)\end{array}$ & $\begin{array}{c}-0.196 \\
(0.947)\end{array}$ & 124 & 0.48 & 0.47 \\
\hline$(2)$ & $\Delta$ ln Mortgages & $\begin{array}{l}-0.555 \\
(0.452)\end{array}$ & $\begin{array}{c}-0.788^{* *} \\
(0.394)\end{array}$ & $\begin{array}{c}-0.771^{* * *} \\
(0.282)\end{array}$ & $\begin{array}{c}-0.459^{* * *} \\
(0.159)\end{array}$ & 124 & 0.33 & 0.06 \\
\hline (3) & $\Delta \ln$ Term loans (domestic) & $\begin{array}{l}-0.592 \\
(0.465)\end{array}$ & $\begin{array}{c}0.264 \\
(0.659)\end{array}$ & $\begin{array}{c}0.016 \\
(0.444)\end{array}$ & $\begin{array}{l}-0.059 \\
(0.281)\end{array}$ & 124 & 0.28 & 0.47 \\
\hline$(4)$ & $\Delta \ln$ Term loans (foreign) & $\begin{array}{l}-3.013 \\
(1.998)\end{array}$ & $\begin{array}{c}-4.850 * * \\
(2.038)\end{array}$ & $\begin{array}{c}-1.970^{* * *} \\
(0.765)\end{array}$ & $\begin{array}{l}-1.510 \\
(0.989)\end{array}$ & 112 & 0.41 & 0.02 \\
\hline$(5)$ & $\Delta \ln$ Other loans & $\begin{array}{c}-3.743^{* *} \\
(1.518)\end{array}$ & $\begin{array}{l}-1.056 \\
(2.970)\end{array}$ & $\begin{array}{c}-0.909 \\
(0.920)\end{array}$ & $\begin{array}{c}-0.057 \\
(1.238)\end{array}$ & 124 & 0.28 & 0.03 \\
\hline (6) & $\Delta \ln$ Securities & $\begin{array}{c}-1.322^{* * *} \\
(0.408)\end{array}$ & $\begin{array}{c}-1.060^{* *} \\
(0.513)\end{array}$ & $\begin{array}{c}-0.687^{* *} \\
(0.282)\end{array}$ & $\begin{array}{l}-0.309 \\
(0.230)\end{array}$ & 124 & 0.42 & 0.00 \\
\hline (7) & $\Delta \ln$ Other assets & $\begin{array}{l}-1.946 \\
(1.566)\end{array}$ & $\begin{array}{l}3.384^{*} \\
(2.053)\end{array}$ & $\begin{array}{c}-0.090 \\
(0.446)\end{array}$ & $\begin{array}{c}-0.142 \\
(0.432)\end{array}$ & 124 & 0.40 & 0.23 \\
\hline (8) & $\Delta \ln$ Total assets (domestic) & $\begin{array}{c}-0.915^{* *} \\
(0.384)\end{array}$ & $\begin{array}{c}0.206 \\
(0.646)\end{array}$ & $\begin{array}{l}-0.046 \\
(0.318)\end{array}$ & $\begin{array}{l}-0.150 \\
(0.312)\end{array}$ & 124 & 0.29 & 0.14 \\
\hline$(9)$ & $\Delta \ln$ Total assets & $\begin{array}{c}-0.920 * \\
(0.526)\end{array}$ & $\begin{array}{c}0.760 \\
(0.658)\end{array}$ & $\begin{array}{l}-0.324 \\
(0.280)\end{array}$ & $\begin{array}{c}-0.263 \\
(0.220)\end{array}$ & 124 & 0.39 & 0.06 \\
\hline \multicolumn{9}{|c|}{ Panel B: Growth in funding } \\
\hline$(10)$ & $\Delta \ln$ Interbank liabillities & $\begin{array}{c}4.512 \\
(6.125)\end{array}$ & $\begin{array}{c}6.246^{* * *} \\
(2.330)\end{array}$ & $\begin{array}{c}0.500 \\
(1.662)\end{array}$ & $\begin{array}{c}0.354 \\
(2.180)\end{array}$ & 122 & 0.37 & 0.40 \\
\hline$(11)$ & $\Delta$ ln Retail deposits & $\begin{array}{c}-1.224^{*} \\
(0.677)\end{array}$ & $\begin{array}{l}-3.338 \\
(2.070)\end{array}$ & $\begin{array}{c}-0.819^{* *} \\
(0.410)\end{array}$ & $\begin{array}{l}-1.501 \\
(1.189)\end{array}$ & 124 & 0.37 & 0.03 \\
\hline$(12)$ & $\Delta \ln$ Wholesale deposits & $\begin{array}{c}-4.215^{* *} \\
(1.788)\end{array}$ & $\begin{array}{c}0.457 \\
(1.599)\end{array}$ & $\begin{array}{l}-0.702 \\
(0.896)\end{array}$ & $\begin{array}{c}0.122 \\
(0.325)\end{array}$ & 124 & 0.29 & 0.02 \\
\hline$(13)$ & $\Delta \ln$ Other debt & $\begin{array}{l}-1.129 \\
(1.239)\end{array}$ & $\begin{array}{c}2.048 \\
(1.631)\end{array}$ & $\begin{array}{c}-0.847^{* *} \\
(0.418)\end{array}$ & $\begin{array}{l}-0.900 \\
(0.627)\end{array}$ & 124 & 0.38 & 0.10 \\
\hline (14) & $\Delta \ln$ Total liabilities & $\begin{array}{l}-1.004^{*} \\
(0.555)\end{array}$ & $\begin{array}{c}0.836 \\
(0.681)\end{array}$ & $\begin{array}{l}-0.330 \\
(0.289)\end{array}$ & $\begin{array}{l}-0.270 \\
(0.235)\end{array}$ & 124 & 0.39 & 0.05 \\
\hline$(15)$ & $\Delta \ln$ Common equity & $\begin{array}{c}0.398 \\
(0.267) \\
\end{array}$ & $\begin{array}{l}-0.048 \\
(0.426)\end{array}$ & $\begin{array}{c}-0.266^{* *} \\
(0.135)\end{array}$ & $\begin{array}{l}-0.273 \\
(0.217)\end{array}$ & 124 & 0.49 & 0.64 \\
\hline
\end{tabular}

